Article

\title{
Distant Interactions, Power, and Environmental Justice in Protected Area Governance: A Telecoupling Perspective
}

\author{
Sébastien Boillat ${ }^{1, * \mathbb{D}}$, Jean-David Gerber ${ }^{1,2}$, Christoph Oberlack ${ }^{1,3}$, Julie G. Zaehringer ${ }^{3}{ }^{(\mathbb{D}}$, \\ Chinwe Ifejika Speranza ${ }^{1}$ and Stephan Rist ${ }^{1,3}$ \\ 1 Institute of Geography, University of Bern, CH-3012 Bern, Switzerland; \\ jean-david.gerber@giub.unibe.ch (J.-D.G.); christoph.oberlack@giub.unibe.ch (C.O.); \\ chinwe.ifejika.speranza@giub.unibe.ch (C.I.S.); stephan.rist@cde.unibe.ch (S.R.) \\ 2 Center for Regional Economic Development (CRED), University of Bern, CH-3012 Bern, Switzerland \\ 3 Centre for Development and Environment, University of Bern, CH-3012 Bern, Switzerland; \\ julie.zaehringer@cde.unibe.ch \\ * Correspondence: sebastien.boillat@giub.unibe.ch; Tel.: +41-31-631-52-67
}

Received: 31 July 2018; Accepted: 28 October 2018; Published: 30 October 2018

check for updates

\begin{abstract}
Equity has become a major concern in efforts to conserve nature. However, in the Global South, inequitable social impacts of conservation usually prevail. We investigate barriers to equitable governance of four protected areas through an innovative approach linking the tri-dimensional framing of environmental justice with the notion of telecoupling. We conceptualize the creation, support, and implementation of protected areas as telecoupling processes that involve flows, actors, and action situations, and assess them based on a set of indicators of procedural justice, distributive justice, and recognition. We perform the analysis for parallel or competing telecoupling processes that affect the areas and we then investigate the scope and reach of resistance actions to attain more equitable outcomes. Identified barriers include dependence of the PAs on transnational financial flows, presence of competing extractive demands, negative narratives on local practices, wilderness and Malthusian framings, authoritarian rule, narrow development options, and socio-cultural discrimination. These combined barriers create multiple forms of exclusion. Resistance actions are likely to succeed when actors can mobilize alliances and resources across distance. We conclude that justice framings can make power relationships in telecouplings more visible, and that considering distant interactions can elucidate causes of (in)equity in conservation.
\end{abstract}

Keywords: telecoupling; protected areas; environmental justice; political ecology; equitable conservation; conservation and development

\section{Introduction}

Protected areas (PAs) are geographical spaces dedicated specifically to the conservation of nature and are the main instrument intended to curb the global biodiversity crisis [1]. Though PAs now cover about $15 \%$ of the Earth's land surface [2], the globally agreed 2010 biodiversity targets have not been met [3] and biodiversity loss is accelerating [4,5]. This challenge has been attributed to insufficient PA coverage [6] and increasing resource use demand that exert pressure on PAs [7]. In the tropics, a major concern is the effectiveness of PAs [8]. Furthermore, a growing number of studies have highlighted the actual or potential negative social impacts of PAs on poor or marginalized people in low and middle-income countries [9-11], and the growing social conflicts within and around conservation areas in these regions [12,13]. 
For these reasons, recent research has brought attention to the key role of equity issues in PA governance $[14,15]$. The centrality of equity issues builds on moral concerns that consider equitable governance as inherently good, as well as instrumental concerns $[16,17]$ based on evidence that PA effectiveness is likely to improve with increased empowerment of local populations and more equitable sharing of conservation benefits $[18,19]$. Yet assessing and improving equity in PA governance faces three prominent challenges. First, equity in PA governance has been mainly framed in distributional terms, with a focus on monetary and material costs and benefits, overlooking other components of well-being and the causes of these distribution patterns [16]. Second, these equity concerns have also been assessed at local or national scales, often with limited attention to injustices that arise from transboundary interactions in PA governance. Third, there is little research on the role of local actors and their bargaining power to advance transformation towards more equitable governance of PAs.

This contribution has therefore the objective to contribute to identify and understand barriers to more equitable governance of PAs and transformation options. Several conceptual refinements need to be integrated to understand better decision-making and equity issues in PA governance. First, one needs to frame equity as a multi-dimensional outcome. For this, we use the three-dimensional framing of environmental justice, which considers equity as an outcome of the three interacting dimensions of distribution, representation and recognition $[16,20]$. Second, one needs to understand natural resource governance as a cross-scale process that involves distant social-ecological ties, including distant actor networks. For this, we build on the umbrella concept of telecoupling, which proposes to focus on flows to assess causes and consequences of land use changes that are driven by distant interactions [21,22], and on recent conceptual developments addressing the polycentric nature of governing telecoupled systems [23]. Third, one needs to make explicit the drivers of equity (or inequity) in these governance processes, as well as the power asymmetries that underpin them. For this, we assess the relationships between decision-making processes and indicators of equity as well as the scope of local resistance actions on the identified drivers, using a network of action situations framing [24].

In this contribution, we examine four examples of PA spaces from Africa and South America by addressing multi-dimensional equity in PA governance from a transboundary perspective and from the perspective of transformation actions. We argue that the telecoupling framework can benefit to the environmental justice framework by extending it beyond distribution and proximity [25], and that combining the environmental justice and action situation frameworks can make power asymmetries and governance challenges visible in telecoupled systems.

The paper is organized as follows. In Section 2, we review recent developments in scholarship on environmental justice and telecoupling, respectively. Section 3 presents the approach and methodology used, Section 4 presents the four investigated cases and Section 5 analyzes and discusses barriers to equitable governance and resistance actions. Section 6 summarizes relevant conclusions for the concepts of environmental justice and telecoupling.

\section{Environmental Justice in Telecoupled Systems}

\subsection{Equity and Justice: A Three-Dimensional Understanding}

John Rawls's landmark in the theorization of justice drew a clear boundary between justice and legality, and focused on the distribution of goods and the establishment of fair procedures to enable just distribution [26]. Amartya Sen further advanced and refined this theory by opening up criteria of justice and injustice to the plurality of values, defining a broader set of capabilities to be enabled through just distribution and procedure [27]. This development has led to acknowledge the fundamental need to incorporate the actors' own perspective of justice beyond a top-down, narrow definition. In a parallel way, Nancy Fraser has theorized on the conditions that enable fair procedures, focusing on the "parity of participation" according to which social arrangements must permit all members of society to interact with one another as peers [28]. She showed that to ensure this, the 
distribution of resources and the social status of peers play a key role, highlighting the intertwined nature of economic, cultural, and political inclusion and exclusion processes.

These theoretical developments have converged towards a three-dimensional understanding of justice, which involves mutually interacting and reinforcing dimensions of distribution, recognition and procedures. Distribution deals with inequality in the distribution of goods, responsibilities, risks and impacts [25]. Procedural justice deals with the fairness of decision-making processes in which those affected are or are not adequately represented in these processes. Recognition addresses the status, respect and valuation attributed or denied to individuals and communities [29,30], and crystallizes the social context in which distribution and participation happen. It is a relational notion that addresses the (dis)respect that one receives from others towards one's identity and culture [16]. Instead of prevailing over each other, these dimensions are intertwined and mutually reinforcing and must, therefore, be assessed altogether to evaluate contexts in terms of equity and justice.

\subsection{Environmental Justice in Conservation Contexts}

Environmental justice (EJ), a specific framing of justice dealing with environmental issues, can also be conceptualized in terms of distribution, procedure and recognition [31]. Born as a social movement and further developed as an analytical tool, EJ has traditionally addressed the disproportionate exposure of disadvantaged groups such as ethnic and racial minorities to environmental burdens such as waste landfills, especially in the American urban context [32-34]. By examining empirically environmental justice movements in the USA, David Schlosberg [35] could show that they indeed refer to the three dimensions of distribution, procedures and recognition in their scopes and claims.

In addition to this conceptual expansion into multiple dimensions of justice, EJ has also expanded in thematic scope, addressing a wide array of environmental issues such as food systems [36], biodiversity conservation [37], and ecosystem services [38], all related with inequities in human-environment relationships. The application of the three-dimensional framing of justice to biodiversity conservation and PA governance is of particular interest to us in this paper. In PAs, these dimensions acquire particular meanings. Distribution is a key issue in benefit-sharing [39] and in payments for ecosystem services [40] schemes, and procedural justice resonates with the wide literature on participatory conservation, community-based conservation and co-management [15,41]. With the Convention on Biological Diversity explicitly highlighting the need to protect cultural diversity and the identity of indigenous peoples, and the observed spatial overlap between PAs and areas of high cultural diversity [42], recognition opens up space for pluralism in knowledge and values related to nature and is highly relevant to conservation [43].

These considerations have led to the development of frameworks to assess equity in PA governance [44-46]. These frameworks include a list of key questions to be assessed from both the examination of PA governance and the subjective perception of equity from the involved actors in relation with the three dimensions of EJ. A focus on equity based on these arguments implies that one has to examine human well-being in a broader way than exclusively focusing on material costs and on benefits of conservation that are usually addressed in livelihoods and poverty framings [47] (Table 1).

\subsection{Environmental Justice and Globalization}

In addition to its expansion in three dimensions, EJ has also been increasingly theorized in relation with globalization [48]. This involves considering EJ at various scales of analysis, from the local scale considered in urban and regional governance and planning, to the global scale dealing with global environmental issues such as climate change [49,50], and on national contexts outside the American one. Consequently, EJ has become increasingly connected with approaches developed in the Global South, such as "third world environmentalism" [51], "environmentalism of the poor" [52], and political ecology [53].

Expanding scales of EJ analysis implies redefining the subjects of justice, i.e., those who are considered legitimate in making justice claims in relation with specific social and environmental 
issues [54]. Globalization, with the prevalence of transborder economic and social relations, challenges the "Westphalian" framing, which has implicitly seen members of a nation or citizens of a modern territorial State as the only relevant subjects of justice [55]. Westphalian framings make invisible injustices that transgress borders, and this invisibility represents in itself an injustice [54]. Furthermore and more generally, globalization has also led to question the relevance of territory as the principal space of exercise of political power [55,56]. Replacing national polities with a global polity is nevertheless also problematic, because it gives prevalent power to "the global" over "the local" [57] and is too unspecific to enable actions that address existing relationships between people across distances [54].

Table 1. Indicator system to assess equitable management in PAs.

\begin{tabular}{|c|c|c|}
\hline Equity Criteria & Indicator & Key Question \\
\hline \multicolumn{3}{|c|}{ Recognition } \\
\hline Cultural identity & $\begin{array}{l}\text { Cultural identities of local } \\
\text { stakeholders groups incorporated in } \\
\text { the management of the PA }\end{array}$ & $\begin{array}{l}\text { Have the cultural identities of local } \\
\text { stakeholders groups contributed to the } \\
\text { design and implementation of } \\
\text { management actions in the } \\
\text { protected area? }\end{array}$ \\
\hline Knowledge diversity & $\begin{array}{l}\text { Traditional knowledge systems } \\
\text { included in the management of the } \\
\text { protected area }\end{array}$ & $\begin{array}{l}\text { Are traditional knowledge systems } \\
\text { included in the management of the } \\
\text { protected area? }\end{array}$ \\
\hline $\begin{array}{l}\text { Statutory and } \\
\text { customary rights }\end{array}$ & $\begin{array}{l}\text { Local stakeholders groups gain or } \\
\text { retain their rights in the establishment } \\
\text { or management of the protected area }\end{array}$ & $\begin{array}{l}\text { Do local stakeholders groups retain } \\
\text { their statutory and customary rights } \\
\text { with the establishment or management } \\
\text { of the protected area? }\end{array}$ \\
\hline \multicolumn{3}{|c|}{ Procedure } \\
\hline $\begin{array}{l}\text { Full participation in } \\
\text { decision-making }\end{array}$ & $\begin{array}{l}\text { Local stakeholders groups satisfied } \\
\text { with how decisions are taken }\end{array}$ & $\begin{array}{l}\text { Are local stakeholder groups satisfied } \\
\text { with how decisions are taken in relation } \\
\text { to protected area management? }\end{array}$ \\
\hline Transparency & $\begin{array}{l}\text { Local stakeholders groups accessing } \\
\text { information about management } \\
\text { and planning }\end{array}$ & $\begin{array}{l}\text { Are local stakeholders groups able to } \\
\text { access information about } \\
\text { management planning? }\end{array}$ \\
\hline Access to justice & $\begin{array}{l}\text { Local stakeholders groups resolving } \\
\text { satisfactory disputes due to protected } \\
\text { area establishment or/and } \\
\text { management by existing mechanisms }\end{array}$ & $\begin{array}{l}\text { Are local stakeholder groups able to } \\
\text { satisfactorily resolve disputes by } \\
\text { existing mechanisms? }\end{array}$ \\
\hline Accountability & $\begin{array}{l}\text { Local stakeholders groups knowing to } \\
\text { whom to raise concerns for solving } \\
\text { issues related to management actions }\end{array}$ & $\begin{array}{l}\text { Do local stakeholders groups know to } \\
\text { whom to raise concerns for solving } \\
\text { issues related to management actions? }\end{array}$ \\
\hline $\begin{array}{l}\text { Free, prior and Informed } \\
\text { consent (FPIC) }\end{array}$ & $\begin{array}{l}\text { Free, prior and Informed consent } \\
\text { (FPIC) obtained }\end{array}$ & $\begin{array}{l}\text { Has a Free, Prior and Informed Consent } \\
\text { (FPIC) been obtained in the } \\
\text { protected area? }\end{array}$ \\
\hline
\end{tabular}

\section{Distribution}

Households of local stakeholders Burdens groups relieved of burdens through mitigation actions or comprehensively compensation of them

Households of local stakeholders groups receiving tangible benefits Benefits from management actions in a way that respects culturally accepted distributional principles
Are there actions to mitigate burdens to local stakeholders groups living in or near the protected area?

Do households of local stakeholder groups receive benefits from management actions in a culturally accepted way of benefit sharing? 
Political geographers have thus proposed to question not only the prevalence of territorial states, but also the framing of globalization as an arena encompassing supra-national, national, and sub-national governance levels as territorialized and nested entities [56-58]. Alternatively, they propose to explore and adopt a topological, networked view of globalization as a configuration of multiple localities [59] in which it is also possible to identify actor interactions and power relationships [57]. In such a view, territorial governance is no more conceptualized as opposed to and challenged by flow-based governance [60], but becomes a particular case of network in which political, institutional and regulatory relations converge to enforce a territorialized framing [56].

One can then redefine subjects of justice in line with this topological view. For example, the notion of "communities of risk" [61] is based on the "all-affected principle" that defines subjects of justice from a functional perspective, considering all people that are imbricated in causal relationships with an issue [62]. Fraser [54] finds this notion problematic because of the potentially infinite web of causal relationships that can tie people together. She proposes to define subjects of justice along an "all-subjected" principle, taking into account all those who are jointly subject to a structure of governance that govern their interactions, including state, non-state and transboundary forms of governance and governmentality. In such framing, the perspectives of the "all-subjected" in being taken equitably into account at the different spheres of decision-making appears crucial, bringing the question of power to the center of the analysis.

\subsection{Telecoupling: A Networked Approach of Globalization}

A parallel development that is relevant to understand globalization in socio-environmental systems is the concept of telecoupling, which has been proposed to capture social-ecological connections across distances, in the sense of a "global interregional connectedness" [63] (p. 5). Telecoupling has been defined as "an umbrella concept that refers to socioeconomic and environmental interactions over distances" [21] (p. 1). It represents an extension of existing research on coupled natural-human systems [64], unifying previous concepts that address either natural or human distant interactions by looking at flows, actors (also called agents [21]), causes and effects that link distant social-ecological systems [21]. Telecoupling has been deemed highly relevant to understand the dynamics of land systems, especially when land use change in an area displaces land use to other areas [65], challenging the sustainable governance of these systems.

The notion of flow is central in telecoupling. Flows are defined as "movements of material, energy, or information between the systems that are transferred as a result of actions taken by agents" [21]. Flows can "also incorporate other material and nonmaterial flows, such as humanitarian investments, or human migration, as well as discourses, ideology, information, technology, and know-how" [66] (p. 1). They can be unidirectional or bidirectional, or spread to more distant systems. Their pathways depend on transport networks, social networks and institutions, and ecological networks [21]. Telecoupling, therefore, corresponds to a topological, networked view of social-ecological systems.

The original framing of telecoupling, however, does not encompass institutions and governance processes. Their understanding has been identified as a key direction for further research on telecouplings [21,22]. Recent research [23] has integrated institutional analysis based on the work of Elinor Ostrom and colleagues $[67,68]$ by conceptualizing the governance of telecoupled systems as polycentric. Governance in telecoupled systems takes place in networks of action situations, in which interactions between proximate and distant actors and processes lead to specific outcomes in terms of sustainability and equity [23]. Action situations are the "social spaces where individuals interact, exchange goods and services, solve problems, dominate one another, or fight (among the many things that individuals do in action situations)" [69] (p. 11).

Institutional analysis does not, however, make power asymmetries and equity issues visible [70]. In Ostrom's theory, political equality is not a pre-condition to design institutions that efficiently govern natural resources [71], and institutions that fit social-ecological systems are not necessarily equitable [70]. Understanding power asymmetries in telecoupled systems has also been identified 
as a key research need [72]. In this contribution, we assume that equity outcomes reflect power relationships at work in polycentric governance processes. We, therefore, believe that integrating EJ criteria into the study of these systems can provide clues about existing power asymmetries among actors who govern and/or who are subjected to telecouplings.

\subsection{PAs as Networked Social Spaces of Justice and Injustice}

Interpreting biodiversity conservation issues with a topological perspective building on the notion of telecoupling has several implications. Biodiversity loss is increasingly tied to processes related with globalization, including the fast expansion of agricultural development, species overexploitation, the spread of invasive species and diseases, the construction of large-scale rural and industrial infrastructure, urbanization, and climate change [73]. These processes are closely related to flows of agricultural goods, species, financial flows and flows of people. Furthermore, justice issues become prevalent when the globalization of trade opens up the possibility for affluent consumers to transfer environmental impacts to distant places of production [65,74]. For example, high-income countries can import biodiversity-threatening products from low-income but biodiversity-rich countries, thus driving biodiversity loss there $[75,76]$. For this reason, in this article we focus on PAs located in the tropical Global South, where distant interactions are tied to equity issues at global and local scales.

The creation of PAs and other biodiversity conservation efforts can be interpreted in two different ways in relation with telecouplings. First, PAs can be understood as "a response to telecouplings". In this sense, PAs demarcate territories that ought to be protected from flows that harm biodiversity. They can be the result of environmental concerns about the impacts of trade flows that can emerge in the system where these flows originate, representing a feedback loop in telecoupled systems [77]. Second, PAs can also be considered "telecoupled" territories that rely on networks and flows for their creation, implementation and enforcement. In this sense, they represent networks intended to compete with biodiversity threatening networks, rather than territories opposing to networks (see Painter [56]). As a matter of fact, PAs in the Global South are heavily dependent on financial flows, including "biodiversity aid" that channels money from cash-rich to biodiversity-rich countries for their implementation and management [78] and incomes from international tourism [79]. They also rely on flows of information and ideas: global conservation priorities, such as "biodiversity hotspots" [80] and the global coordination of conservation actions [9], distant expertise including standardized monitoring and evaluation methods and the promotion of globally shared environmental and landscape values [81], and a global managerial culture in PA governance [82,83].

These considerations have several implications on justice issues in telecoupled conservation contexts. First, the identification of subjects of justice according to the "all-subjected" principle means that focus has mainly to be given on those who must permanently obey the rules of the PAs, namely the people who live within and around the PAs, but also more distant actors who could potentially benefit from the extraction of resources prohibited by the PA. Therein, however, lies a paradox, because both the creation of PAs and the extraction of resources in such "globalized" contexts implies transforming biodiversity and untouched nature into commodities that consumers can appropriate across a global economic system [84]. Thus, the expansion of both resource use and nature conservation can be framed as commodity frontiers [85], in which PAs are also part of the global process of transformation of land, labor and money into fictitious commodities [86,87]. PAs are, therefore, at the meeting point of two contradictory social-ecological valuation systems that aim on the one hand at protecting "nature" from becoming a commodity — setting it aside from the market forces—and on the other hand at turning it into a commodity to cover the costs of its protection. The presence of this "double commodity frontier" of resource extraction and conservation can be interpreted as an "injustice at intersecting scales" involving multiple sources of coercion and exclusion [88], which are particularly challenging for the local, poor, and marginalized populations of the targeted areas. 


\subsection{Barriers, Opportunities, and Transformation Options for EJ}

The considerations above raise the question on how more equitable PA governance can be attained in transboundary conservation contexts. First, the links between telecoupling processes and EJ outcomes can be assessed by examining the position of local communities in terms of recognition, procedures and distribution within the different action situations that govern the telecouplings that affect their livelihoods. These links can take the form of dominant discourses and narratives, economic pressures, or political, social, cultural, and economic configurations of power, and arise from networks involving global, transboundary, national or local social spaces. Depending on whether they favor or not local communities, these links represent barriers and opportunities to EJ, and they crystallize into EJ outcomes in terms of recognition, procedures and distribution.

Second, one can examine what kind of actions the affected communities take to attain better outcomes in terms of EJ, and whether they actually have the power to fit with the relevant action situations identified through the telecoupling approach. One can also ask to what extent such actions represent emancipatory movements, which focus on eliminating domination and achieve capabilities through justice beyond the dominant and antagonistic forces of marketization and social(-ecological) protection [89]. While emancipation actions may build alliances with marketization or social protection against the third pole [89], they also have a spatiality, which represents the options that local communities have or do not have to reach to be part of the action situations to which they are subjected. In this study we, therefore, concentrate on (1) the identification of links between action situations that govern telecouplings and multi-dimensional EJ outcomes, and (2) the scope of observed resistance actions to improve these outcomes. Our hypothesis is that actions that target relevant action situations and increase recognition of the interested groups to obtain parity of participation in these situations are more likely to succeed.

\section{Approach, Materials, and Methods}

We conceptualize PAs as contexts characterized by multiple telecouplings involving the interplay of tied systems, flows and actors [90] (Figure 1). First, PA creation, support, and governance are framed as a telecoupling process. This process can evolve to a new telecoupling when the distant ties, flows and PA governance significantly changes to represent a new phase of the PA history [91]. Then, we examine telecouplings that run in parallel and potentially or actually compete with the conservation telecoupling process.

Telecoupling processes are driven and governed by multiple action situations, which can also be complementary or compete with each other. These action situations may include decision-making arenas, in which formal and informal decisions, punctual decisions or aggregates of decisions that are embedded into management practices are taken. Thus, decision-making arenas can include specific agreements, governance bodies, public policies, or management actions.

Figure 1 shows the elements of our approach. From the point of view of a focal system, action situations can be located within the system, in distant systems or on the flows that tie these systems together. This corresponds to focal, flow-centered and distant action situations [23]. Their interplay (full arrows in Figure 1) along a telecoupling process produces specific outcomes in the focal system, which can be evaluated in terms of recognition, representation, and distribution using a modified version of the EJ indicators proposed by Zafra-Calvo et al. [44] for PAs. We conceptualize networks of interplay between action situations and EJ outcomes as power-laden links (dotted lines in Figure 1) expressed in political, social, discursive, cultural, and economic terms. Based on Zafra-Calvo et al. [44], we labelled EJ outcomes as "equitable", "inequitable", or "partly equitable", depending on how the key questions detailed in Table 1 can be answered. Resistance actions then seek to influence decision-making processes in focal or distant arenas or on flows that tie them, feeding back into the EJ outcomes. Table 2 shows the steps to be performed to make these elements and their ties visible.

In this contribution, we performed the mentioned steps for four cases of PAs: Masoala National Park in Madagascar, Tunari National Park in Bolivia, Nech Sar National Park in Ethiopia, and Galapagos 
National Park and Marine Resource Reserve in Ecuador (Table 3). To answer the questions, we chose to rely on rich and already existing literature on the selected areas, partly complemented with own field expertise and interviews of experts. Case selection responded to following criteria: (1) location in the "Global South", i.e., lower or lower-middle income countries with colonial or invasion history, in which power relationships across distances are likely to be identifiable; (2) relatively long-standing PAs (min. 20 years since creation), so that social-ecological impacts of implementation were visible; (3) different types of ties with distant systems that are likely to influence EJ outcomes; (4) different socio-political contexts that enable or disable resistance and transformation actions; (5) comparable categories of protection: category of National Park (IUCN category II), of which the main purpose is nature and biodiversity conservation with a few economic activities permitted such as tourism [92]; and (6) sufficient available information on flows from different perspectives and at different scales.

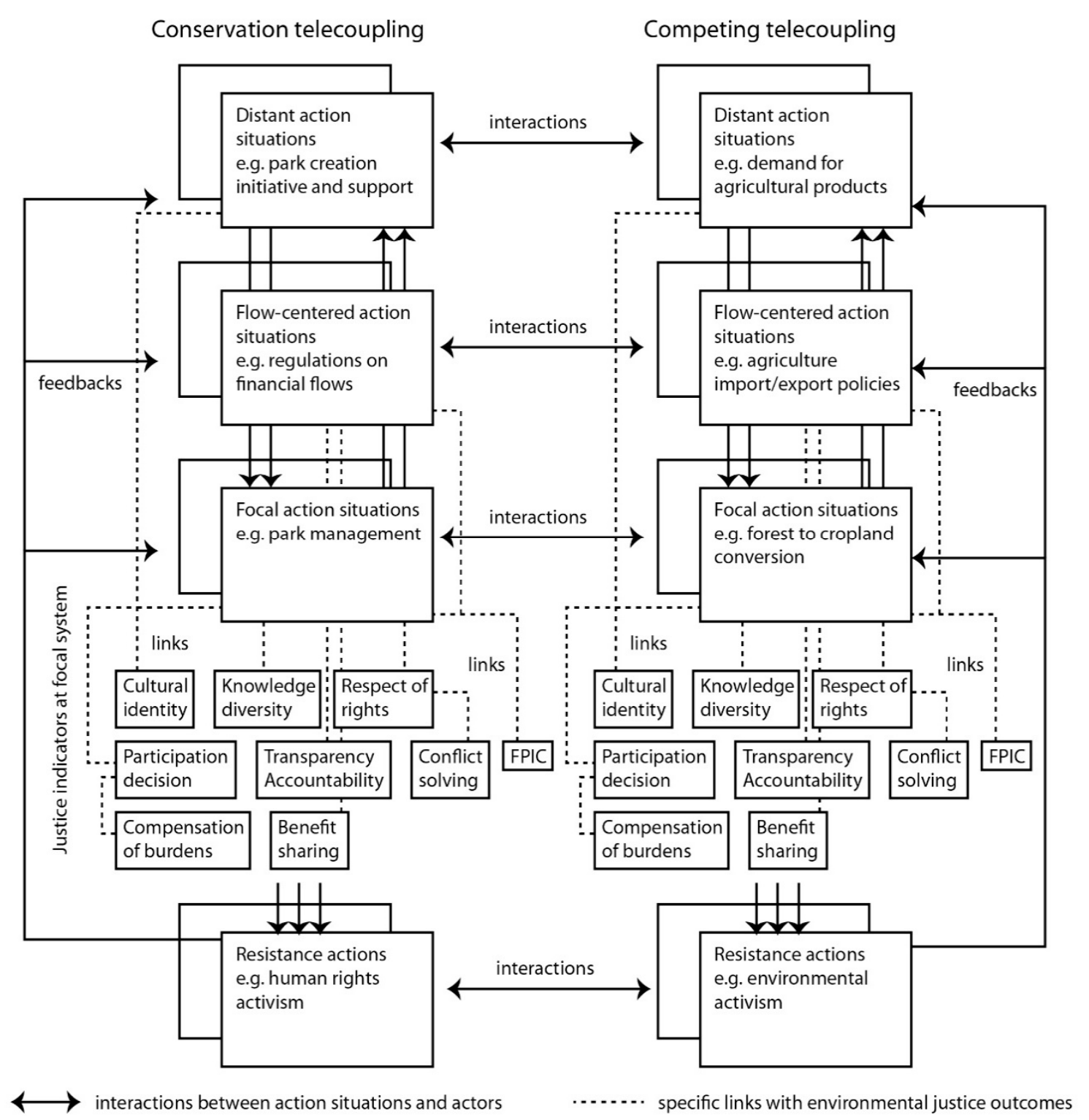

Figure 1. Framework linking conservation and competing telecoupling processes with environmental justice outcomes and resistance actions. Source: Authors, based on Oberlack et al. 2018 [23]. 
Table 2. Steps taken to assess environmental justice in telecoupled conservation contexts.

\section{A. Characterization of Telecouplings}

1. How has the creation, support and governance of the PAs been tied through flows and distant systems?

2. What are the flows that tie the PAs and their immediate surroundings to other systems that complement and possible compete with the PAs?

3. What are the decision-making arenas, in a broad sense, that characterize these telecoupling processes in distant, flow-based and focal contexts?

\section{B. Environmental Justice Outcomes}

4. How are local communities recognized in relation with the studied telecoupling process, including (1) respect of their cultural identity, (2) respect of their knowledge, and (3) respect of their statutory and customary rights? (Recognition)

5. To what extent do local communities participate in the identified decision-making arenas, including

(1) satisfaction with how decisions are taken, (2) access to information and accountability processes,

(3) access to conflict resolving mechanisms? (Representation)

6. Did local communities give their free, prior and informed consent to engage into the examined telecoupling process? (Representation)

7. Are the burdens on local communities that result from the telecoupling process mitigated by satisfactory compensations? (Distribution)

8. Are the benefits to local communities that result from the telecoupling process culturally acceptable and equitably distributed? (Distribution)

\section{Barriers, Opportunities and Resistance}

9. What are the key elements of power relationships that link recognition, representation or distribution outcomes with specific focal, flow-based and distant decision-making processes of the telecoupling process?

10. What are the resistance strategies performed by focal and distant actors aiming at EJ outcomes? Which specific focal, flow-based and distant decision-making processes of the telecoupling process do they target?

Table 3. Main characteristics of the four studied protected areas.

\begin{tabular}{|c|c|c|c|c|}
\hline Protected Area & $\begin{array}{c}\text { Masoala National } \\
\text { Park }\end{array}$ & $\begin{array}{c}\text { Tunari National } \\
\text { Park }\end{array}$ & $\begin{array}{c}\text { Nech Sar National } \\
\text { Park }\end{array}$ & $\begin{array}{c}\text { Galapagos National Park } \\
\text { and Marine Reserve }\end{array}$ \\
\hline Country & Madagascar & Bolivia & Ethiopia & Ecuador \\
\hline Total area & $2100 \mathrm{~km}^{2}$ & $3090 \mathrm{~km}^{2}$ & $514 \mathrm{~km}^{2}$ & $7996 \mathrm{~km}^{2} / 138,000 \mathrm{~km}^{2}$ \\
\hline IUCN category & II (National Park) & II (National Park) & II (National Park) & II (National Park) \\
\hline Biome type & $\begin{array}{l}\text { Tropical forest; } \\
\text { tropical coastal }\end{array}$ & $\begin{array}{l}\text { Tropical dry } \\
\text { mountains }\end{array}$ & $\begin{array}{c}\text { Savannah; } \\
\text { tropical freshwater }\end{array}$ & Tropical coastal \\
\hline
\end{tabular}

Though we did not use the presence of conflicts in the PAs as a selection criterion, all cases appeared to have experienced conflicts at times between PA management and local populations. It is possible that these conflicts have motivated the pursuit of existing studies on social impacts, governance and participation we relied on. Thus, we do not exclude a bias towards conflictive or challenging PA contexts, but we believe that these are frequent contexts in the global South [93] and that they would benefit from a combined telecoupling and EJ approach. 
Due to the large number of possible interactions between flows, actors, decision-making processes, and their distributive, procedural, and recognition outcomes, we use a qualitative approach also used by other tri-dimensional EJ studies [37,94], to assess them. We collected data from four main sources of information. First, we gathered peer-reviewed, scientific literature on the chosen PAs, using the name of the PA and the region it is located in as keywords. To narrow down the search to studies on social aspects, we used these keywords in combination with "governance", "participation", "social impacts", and "co-management". Second, we consulted grey literature on the PAs, including reports by environmental NGOs and IOs's on the areas, which are often cited in peer-reviewed studies. We processed them the same way as with peer-reviewed sources, but privileged the latter information if it overlapped. To ensure that the most important information is covered, we used snowball sampling to select literature, gathering information until no new insights on telecoupling process and EJ outcomes were found. We then performed semi-structured expert interviews by contacting the authors of these studies or reports, asking them to (1) identify the local and distant flows that occur within or in the surroundings of the PAs, (2) the actors that enable, benefit or are affected by each of these flows, and (3) how decisions relevant to these flows were taken, who participated and, when possible, how actors perceived one another. After the expert interviews, we performed a second round of literature review if new flows appeared and we included studies that specifically address ties with distant systems. Finally, for two cases, we relied on the field experience of two of the authors (J. G. Zaehringer for Masoala and S. Boillat for Tunari) who performed and published research on these areas.

\section{Results}

In the four examined cases, PA creation and their subsequent implementation and management involved flows of funds, information, ideas, and people. International funding and expertise came almost exclusively from the USA and Western Europe. In addition to conservation as telecoupling processes, flows of natural resources, people, and funding that competed with conservation were at work in the four examined cases (Figure 2). Some were tied to Asian demand for timber and sea products, but others were also tied to domestic demand, such as water, fuelwood and land for urban areas. Finally, some flows were enhanced by conservation, such as international tourism in the Galapagos, or export crop agriculture around Masoala.

\subsection{Masoala National Park, Madagascar}

Masoala National Park was enacted 1997 through a co-management agreement between Malagasy national government and the local branch of U.S. based Wildlife Conservation Society (WCS), on the basis of prospective studies performed by WCS and supported by USAID. These studies demarcated the area according to biodiversity richness, absence of human use, and a buffer zone [95]. Since then, private donors have financially supported the park, especially the Zoo of Zurich in Switzerland, who has opened a permanent exhibition artificially reproducing the Masoala forest in an about 1-hectare greenhouse in Zurich [96]. The donors have also promoted international tourism and local development actions [97].

Small farmers living within and around the buffer zone of the park did not participate in decision-making and acted only as information providers on the location of land uses [96]. After the implementation of the park, their traditional activities that include slash-and-burn, agroforestry cultivation and forest product collection were criminalized, and access to the core zone of the park, which included a burial site, was banned; this led to land access losses and food shortages for some families [96]. Development actions such as agricultural extension and support to irrigation, health and education services, provided benefits at the beginning but were later stopped [97]. 


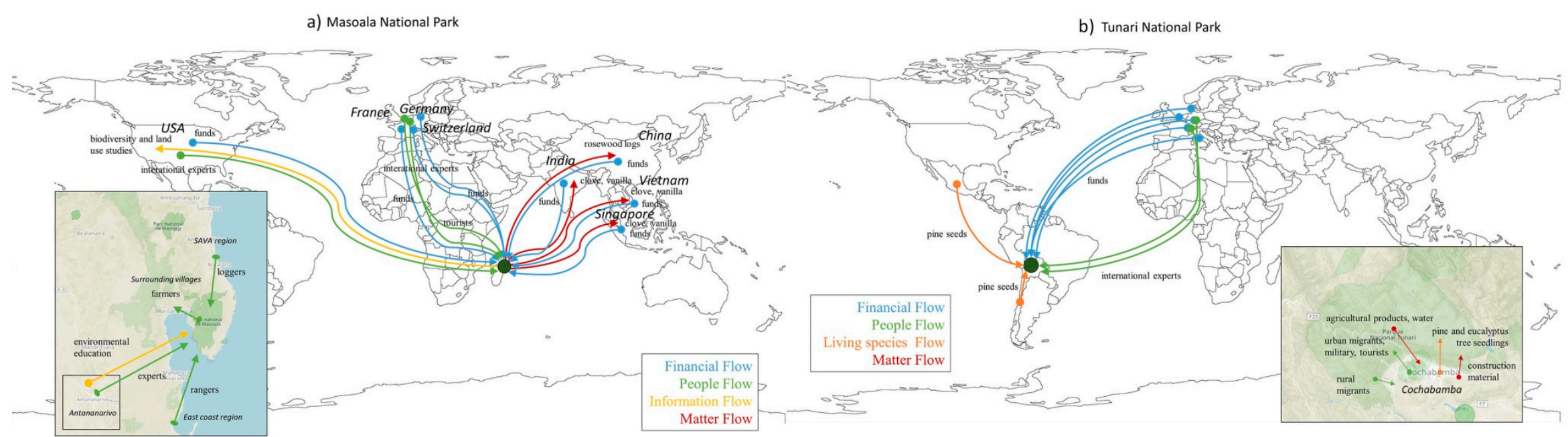

c) Nech Sar National Park

d) Galapagos National Park and Marine Resource Reserve

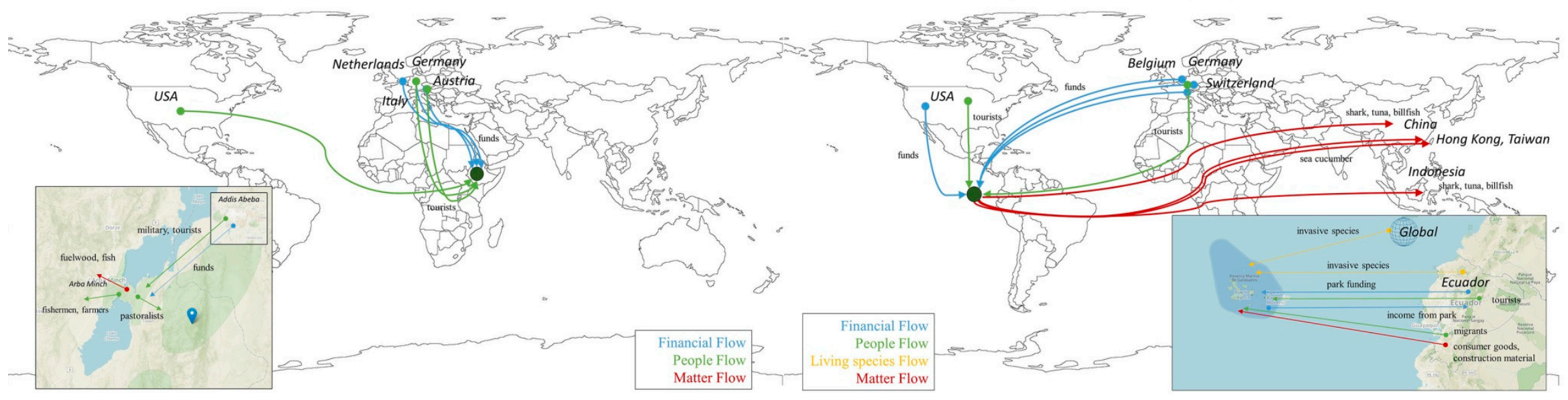

Figure 2. Representation of the main flows that tie the four studied PAs to distant, national and local systems. 
These deficient equity aspects in park governance can be first traced back to a prevalent "fire superstition" narrative on Malagasy traditional farming which dismisses their use of fire (Link M1 in Figure 3) as a non-sense practice and the main cause for biodiversity decline on the island [98]. This narrative is visible at the Zurich exhibition, where shifting cultivation and use of fire are presented as superstitions and a major threat to biodiversity, leading the park authorities to enforce a strict fire suppression policy [96]. A second narrative on Madagascar in general and Maosala in particular is the strong wilderness approach (M2) which has shaped the demarcation of the park, designed so that no settlements were to be included into its core area, minimizing community involvement [95]. This narrative is also visible in international cultural productions such as the animation movie "Madagascar" which made Swiss children believe that no humans live on the island [96]. For these reasons, development actions aimed at supporting communities were also framed in terms of curbing "irrational" slash-and-burn practices and other culturally devaluated traditions, and were also subject to intermittent funding (M3) which led to unequal benefits. The lack of formal recognition of local land rights (M4), stemming from the nominal but weak presence of the state in the area, adds up to equity issues, hindering land compensation processes.

Despite park regulations, recurrent episodes of extraction of timber in the park, especially rosewood (Dalbergia spp.) and their export to China have occurred, driven by the demand for precious woods as raw material for Ming-style furniture and by more restrictive forest policy in China [99]. The legal voids from the lack of clear identification of rosewood species in CITES regulations and the possibility of exporting wood damaged by cyclones in Malagasy law (M5) made these exports possible through exceptional permits, which were used during a period of political instability to enter the park and exploit timber. Timber extraction provided temporary but risky income for some villagers, but also led to an increase in food prices, crime, and prostitution in the villages [100]. The illegality of extraction and state weakness led regional economic elites to quickly take control of timber resources (M6), increasing further their economic power (M7) and involving lack of equitable work conditions, transparency and benefit sharing in timber extraction. Lack of recognized local land rights (M4) in forests made it possible for a few people to self-declare as forest owners and reap benefits from the extraction [100].

Farmers around Masoala also produce export crops such as cloves (Syzygium aromaticum), which are shipped to Singapore, Indonesia, India, and Vietnam where they are used to make kretek, a traditional Indonesian cigarette [101], and vanilla, shipped to USA and Europe for bakery uses. In this case, equity indicators perform better with agroforestry systems (M8) that led to a valuation of farmer knowledge; and locally recognized land rights (M9), and that enable farmers to freely decide what crops to grow and who to sell to. Export crops generate high incomes for landowning farmers, but these are highly variable due to price fluctuations, cyclones, pests, and theft [102]. In this case, social protection of farmers is also lacking, and a large part of the benefits is captured by exporters, some of them also linked with illegal timber exports (M8).

Villagers and national and international NGOs performed resistance actions. Villagers exerted passive resistance (A) to park implementation (A1), avoiding taking part in environmental education and other activities [96]. They, however, also intended, though unsuccessfully, to block loggers (C1) to enter the park [103]. Swiss researchers have built an alliance with a national NGO to address human rights issues (B) related with the park implementation and raise awareness in Switzerland about it (B1). Finally, international NGOs have exerted advocacy at international scale (D) to include rosewood on the CITES appendix (D1), to build awareness in China to stop rosewood imports (D2), to track shipping companies (D3), and to pressure the Malagasy government to bring illegal loggers and exporters to court (D4) [103]. 
Biodiversity conservation

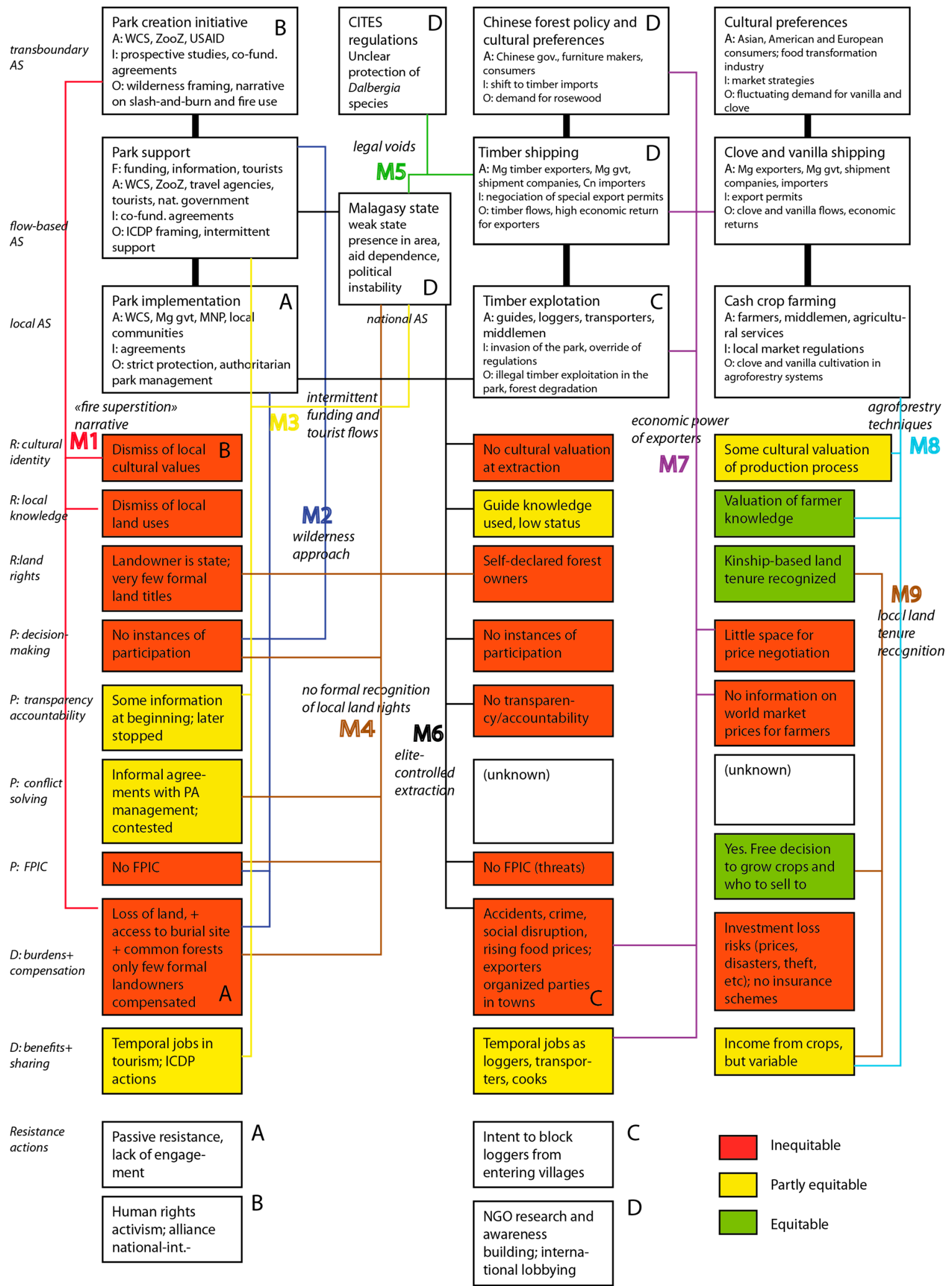

Figure 3. Telecoupling processes and main environmental justice outcomes for Masoala National Park. Abbreviations used: AS = Action Situations; $\mathrm{R}=$ Recognition; $\mathrm{P}=$ Procedure; $\mathrm{D}=$ Distribution; WCS = Wildlife Conservation Society; ZooZ = Zoo of Zurich; ICDP = Integrated Conservation and Development; $\mathrm{Mg}=$ Malagasy; gvt = government; $\mathrm{Cn}=$ Chinese. 


\subsection{Tunari National Park, Bolivia}

The Tunari National Park was enacted 1962 following the proposal of a group of Bolivian urban intellectuals [104], to protect the city of Cochabamba from landslides and establish a recreation area in the nearby mountains. German and then Swiss bilateral cooperation supported forestation activities (mainly with exotic pines and eucalyptuses) in the area, and a consortium involving a Swiss cooperation NGO and the regional government of Cochabamba co-managed the park. Small farmers living within the park have land titles dating back the agrarian reform of 1953. During the forestry phase, they allowed the plantations with the prospect to exploit timber and accepted to give up cultivation and grazing activities.

In 1991, a national law was enacted to expand the park's limits and restrict agriculture and grazing activities in favor of forestry. In 1999, the forestry project closed and the regional government took responsibility of the park. After that, the park authorities banned timber and firewood extraction in plantations in order to "conserve" recreation and protection "forests". Though a park management committee was created in 2000, farmers associations refused to integrate it because it lacked decision power and was subjected to the 1991 law. The exclusion of farming and grazing in the Tunari is linked to a narrative of "irrational" mountain farming (Link T1 in Figure 4) as being inherently responsible for soil degradation and erosion [105], present in the forestry projects' discourse. The counterpart of this discourse is the idea of "development through forestry" (T2) supposed to replace agriculture and provide benefits to farmers. However, when international support stopped, the focus was put on a "recreation and protection forest" narrative (T3), which seeks to create a closed canopy of trees for recreation purposes, thus banning timber production objectives. Though national conservation policies use a participatory discourse (T4), established participation structures do not have the power to challenge the 1991 law or the park's limits. High poverty rate and historic social discrimination (T5) by urban mestizo elites of mountain farmers, who belong mainly to the Quechua indigenous group, represents a barrier for them to access fair procedures, adding up to these equity challenges.

Since 1985, people have migrated from mining towns in crisis and other rural areas of the country to Cochabamba, some of them encroaching into the southern limits of the park. Urbanization pressure combined with the lack of coordinated and effective land planning has favored a strong urban sprawl (T6) around Cochabamba. While urbanization provides job opportunities for farmers, it also favors landowners and local leaders through land sales, it increases land and housing prices, crime and water scarcity, and it occupies traditional grazing lands [106]. Some urban settlements have managed to push back the parks' limits to become legal, but municipalities continue to deny electricity and water services to some rural settlements due to their assimilation to illegal urban settlements in the park. Furthermore, the risk of further urban sprawl into the park (T6) is blocking review of the 1991 law out of fear that allowing agriculture would open up the area to urbanization in a context of deficient land planning.

The Tunari mountains are also an important source of water for the city of Cochabamba and irrigated agriculture in the adjacent valley. To meet growing drinking water, irrigation water and energy demands and perceived water scarcity (T7), the Bolivian government has created the Misicuni company in charge of coordinating the construction of a dam in the Misicuni valley located within the park. The company has been successively supported by the Venezuela-based Development Bank of Latin America (DBLA), U.S. based Interamerican Development Bank (IDB) and Italian bilateral cooperation [107]. Impact mitigation documents also refer to mountain agriculture as a threat to water availability and quality (T1) and social discrimination (T3) is visible in the absence of long-term participatory and benefit-sharing mechanism in compensations for the nine indigenous communities affected by the Misicuni dam lake [107]. To comply international development standards, the Misicuni project donors have supported a concertation process for the elaboration of a new management plan for the park, enacted 2016. In relation with the three processes, land rights (T8) established in the Tunari after the 1953 agrarian reform represent an opportunity for more equitable governance. These rights are 
being updated through a land survey performed by the national agrarian reform institute, though with unequal advance due to intermittent funding sources [108].

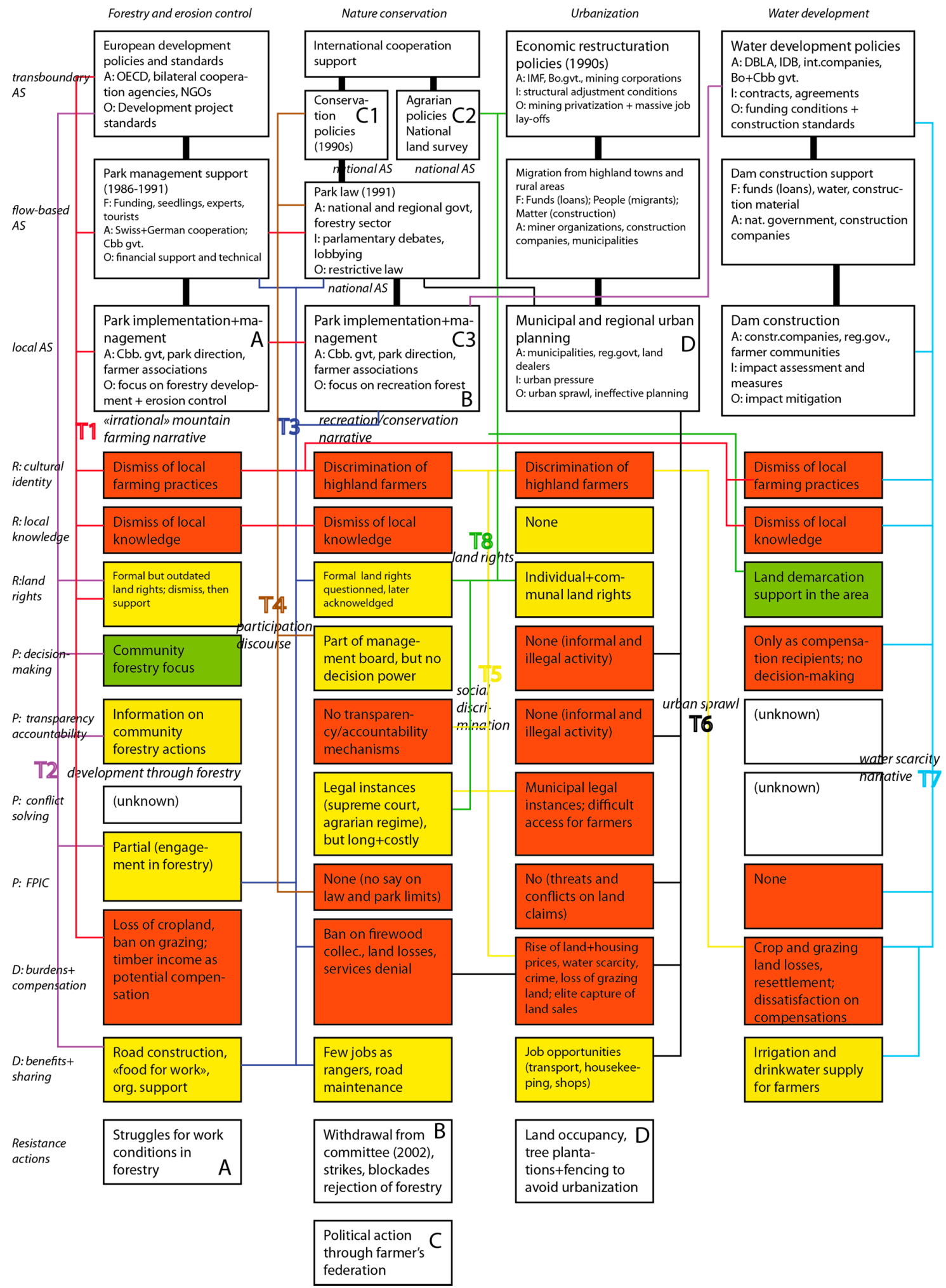

Figure 4. Telecoupling processes and main environmental justice outcomes for Tunari National Park. Abbreviations used: $\mathrm{AS}=$ Action Situations; $\mathrm{R}=$ Recognition; $\mathrm{P}=$ Procedure; $\mathrm{D}=$ Distribution; Bo.gvt $=$ Bolivian government; $\mathrm{Cbb} . \mathrm{gvt}=$ Cochabamba regional government. 
Resistance actions to the observed processes involved first a farmer's struggle for better work conditions in forestry (A), which was negotiated with the Swiss-Bolivian consortium. Farmer associations refused to integrate the park management committee (B), and issued a resolution to stop their involvement in forest plantation projects [106]. They also supported the nationwide political struggle (C) of the Bolivian farm workers' federation, which eventually led President Evo Morales, an indigenous farm union member, to power, leading to a deep restructuration of the State. Farmers also developed a counter-narrative of the human-nature relationship in the area, stressing the need to "care about places" for cultural and religious reasons [106]. These actions enabled the recognition of land rights within PAs at national level (C1), more support for collective lands demarcation (C2), and the inclusion of agrobiodiversity as a conservation objective into the new management plan (C3). Nevertheless, the 1991 law could not yet be reformed. Some farmers communities have performed land occupancies, established fences and planted trees in some areas to avoid urbanization (D).

\subsection{Nech Sar National Park, Ethiopia}

The Nech Sar plains were declared a National Park in 1974 to protect wildlife, on the basis of reports made by British biologists about the site's wildlife richness and the presence of Swayne's hartebeest (Alcelaphus buselaphus swaynei), endemic to Ethiopia. The reports also recommended decreasing or resettling existing cattle in the area to avoid overgrazing [109]. Consequently, the Ethiopian national government under the Derg military regime forcefully evicted about 2000 Guji Oromo pastoralists and Koore farmers living there in 1985 and 1986, without compensation and with devastating effects on their livelihoods $[110,111]$. These outcomes can be related to the combination of a wilderness and wildlife reserve framing (Link N1 in Figure 5) found elsewhere in Africa [112] that excludes human presence in the park, and the military regime (N2) who makes any kind of participation, transparency, and accountability impossible, and denies land rights to local communities.

After the fall of the Mengistu government in 1991, Guji and Koore people returned to the area. In 1995, the park management was handed over to the regional government of Southern Nations, Nationalities, and Peoples' Region (SNNPR). In 2004, an agreement involving the Ministry of Agriculture and the SNNPR handed over the park management to a Netherlands-based NGO, African Parks Foundation (APF), with the tasks to zone and fence the park, to negotiate to resettle pastoralists and farmers, and to develop tourism [110]. APF committed to make the park lucrative by promoting tourism, they increased the park budget by 10-fold, they hired some Guji and Koore as park scouts and they performed cattle vaccinations campaigns [111]. Nevertheless, resettlement negotiations failed due to disagreements between the SNNPR and the neighboring Oromia region. Because the Guji belong to the Oromo ethnic group, it was suggested that Oromia region should grant them land for their resettlement, which they rejected arguing that the park is located within SNNPR. APF accepted to negotiate with the Guji but not to include farmers within the park, which would affect its wilderness character. Consequently, their proposal was rejected by SNNPR who did not accept favoring permanence of the Guji against Koore; APF withdrew from Ethiopia in 2008 [111], and both Koore and Guji were forced out of the park again by governmental forces [110]. It was therefore the combined continuation of the wilderness framing (N1), now tied to tourism business interests (N3), and the conflicts among ethnically framed regional states (N4), which constituted a major barrier to equitable park governance. Subsequent deficient and inequitable park management led more than $80 \%$ of Koore and Guji people to assert that they have no benefits from the park [111]. Ineffective management (N5) resulted, encouraging further use of the park resources by other groups. Following the growth of the city of Arba Minch and the lack of alternative energy sources (N6), firewood collection in the park has increased and threatens forests around water springs, which also supply the city with drinking water [113]. 


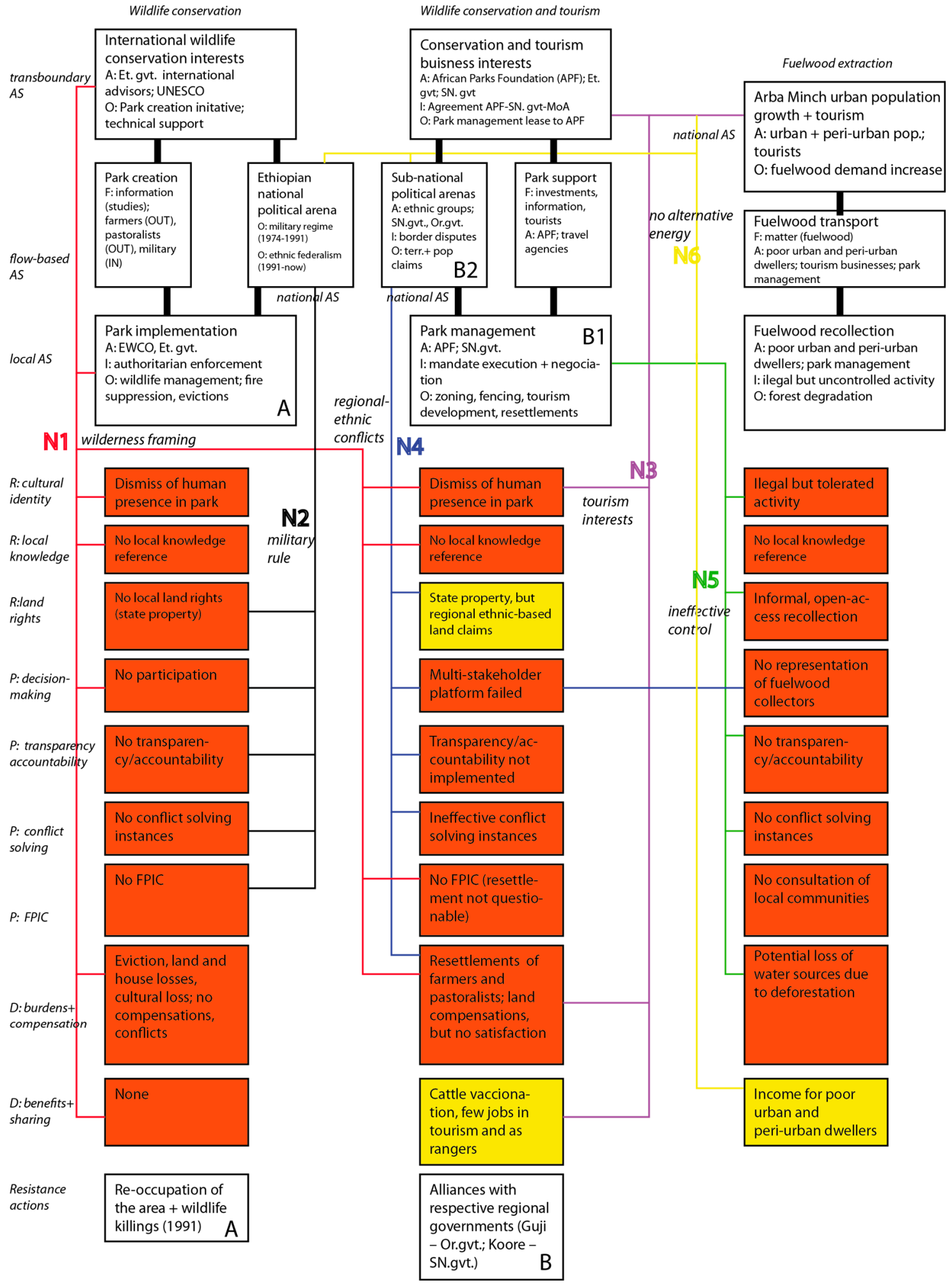

Figure 5. Telecoupling processes and main environmental justice outcomes for Nech Sar National Park. Abbreviations used: AS = Action Situations; $\mathrm{R}=$ Recognition; $\mathrm{P}=$ Procedure; $\mathrm{D}=$ Distribution; Et.gvt = Ethiopian government; SN.gvt = Southern Nations regional government; Or.gvt. Oromia Regional Government; EWCO = Ethiopian Wildlife and Conservation Authority.

Resistance actions started in 1991 when Guji and Koore came back to the park (A). Back then, park infrastructures were looted and wildlife killed. Koore and Guji competed for land and used 
different narratives for their claims: the Koore claimed land based on past administrative jurisdictions, and the Guji invoked ancestral rights [110]. Though both groups were evicted again from the park after 2004, the Guji managed to remain close to the park and exerted passive resistance including cattle trespassing, fire setting, and hunting targeted at Swayne's hartebeests (B1). They also opposed a counter-narrative that attributes shrub encroachment to fire suppression policies [110] instead of overgrazing stated by vegetation studies [114]. Furthermore, they were able to gain Oromia region state officials to their cause (B2) $[110,111]$.

\subsection{Galapagos National Park and Marine Resource Reserve, Ecuador}

Located about $1000 \mathrm{~km}$ off the coast of Ecuador, the Galapagos Islands harbor a unique endemic flora and fauna. Discovered in 1535 by Spanish sailors, the islands were only sporadically visited by whalers until their annexing by Ecuador in 1832, and then settled by colonists from Europe, North America, and Ecuador. Galapagos National Park was enacted simultaneously with the creation of the Belgium-based Charles Darwin Foundation (CDF) in 1959 to celebrate the 100 years after the publication of Darwin's Origin of Species. Since then, the Ecuadorian government has managed the park, with CDF as an official advisor. The park has been supported with millions of dollars from international donors and tourist fees. It protects $97 \%$ of the land on the islands under a wilderness approach and promotes ecotourism relying on the narrative of a "natural laboratory" related with Darwin's studies and the biologists who visited the islands [115]. Thus, actions were focused on maintaining the islands in their "natural" state, removing alien species, managing wildlife and suppressing local agriculture. This wilderness narrative (Link G1 in Figure 6) left no room for inclusive governance. Furthermore, selective tourism (G2) was promoted in order to minimize environmental impacts, favoring cruise boat tourism operated by large companies owned by Americans or mainland Ecuadorians, with little benefits to the islanders [115-117].

In 1998, the Galápagos Special Law was enacted to establish more participatory conservation (G3) promoted by international organizations, but also to expand protection to the marine domain. The law establishes the Galapagos Marine Resource Reserve (GMRR), and a Participatory Management Board (PMB) that includes the park authorities, CDF, tourism, and fishing sectors [115,118]. The PMB's decisions are reviewed, approved and executed by the Inter-institutional management authority (IMA), composed mainly by Ecuadorian government representatives but also the economic sectors $[115,118]$. A more inclusive approach of tourism (G4) was promoted, with redistribution of $25 \%$ of tourist entrance fees income to the three municipalities of the islands [119], and a system of tourism and fishing operation licenses aimed at favoring benefits to local residents [120]. As a result, tourist visits to the park have increased exponentially from 11,000 visitors in 1979 to more than 200,000 in 2014 [115] and come from the USA and Europe in two-thirds of the cases (Grenier, pers. com.). By 2006, the tourism sector provided jobs for $78 \%$ of the active population in the Santa Cruz Island, but only $22 \%$ in the less visited San Cristóbal and 5\% in Isabela [121]. These job opportunities attracted migrants from economically depressed (G6) mainland Ecuador, increasing the island resident population from 1346 in 1950 to more than 25,000 people in 2006 [118], and leading park authorities to limit immigration to avoid pollution and alien species introduction, using a population pressure discourse (G5). Nevertheless, regulations have only been partly effective and many migrants reside in the island without legal status $[118,121]$.

Local and industrial fishing has developed from the 1990 onwards to meet demand from Hong Kong and Taiwan (G7) for sea cucumber (Isostichopus fuscus) due to depletion of stock in other areas of the Pacific [122]. The GMRR first set quotas on sea cucumber catches and later banned their gathering altogether, leading to conflicts with local fishermen. The conflict stopped when sea cucumbers and lobsters fishing ceased to be profitable due to depletion of the resources [115,120]. Nevertheless, illegal fishing of other species, such as sharks, is still occurring in around the islands due to the large extent of the reserve and poor inspection capacity [120]. In August 2017, a Chinese cargo was caught within 
the Galapagos Marine Reserve with 6600 sharks, yet it is unclear whether these were fished in the reserve [123].

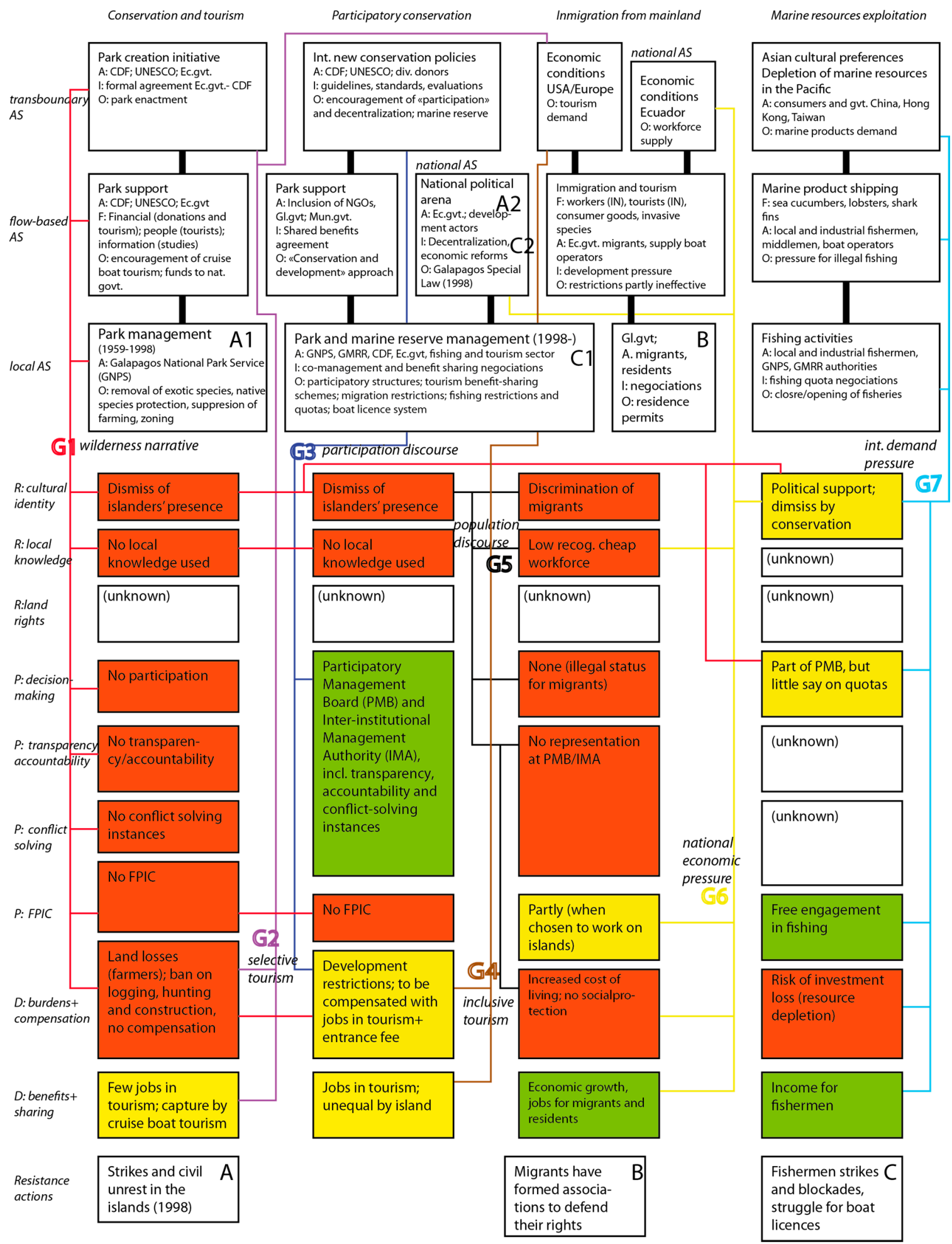

Figure 6. Telecoupling processes and main environmental justice outcomes for Nech Sar National Park. Abbreviations used: AS = Action Situations; $\mathrm{R}=$ Recognition; $\mathrm{P}=$ Procedure; $\mathrm{D}=$ Distribution; $\mathrm{CDF}=$ Charles Darwin Foundation; Ec.gvt = Ecuadorian government; Gl.gvt = Galapagos provincial government; Mun.gvt = Municipal governments; GMRR = Galapagos Marine Resource Reserve. 
A first wave of social protests in Galapagos emerged in the 1980, when 28 tortoises were killed on Isabela, and fire was set to the CDF building [116] (A1). Further strikes and demonstrations enabled the Galapagos islanders to obtain two permanent representatives at the Ecuadorian national congress [115] (A2). This gave them substantial power and enable alliances with political parties [120]. Some migrant groups have formed associations to defend their rights in the islands (Grenier, pers. com.) (B). In the 1990s, fishermen have been protesting against restrictions on sea cucumber fishing (C1), also killing tortoises, damaging CDF infrastructures, striking, and demonstrating. This led to a back-and-forth of fisheries opening ceding to protests, and subsequent closure due to depletion of resources $[115,116]$. Fishermen protests continued even after the establishment of the PMB, demanding access to tourist boat licenses, expressing their dissatisfaction with what they deemed excessive power of CDF conservationists and large tourism operators [115], which can be related to their persisting control of external resources and knowledge despite shared governance $[115,116]$. Fishermen have also built alliances with political parties at national scale (C2) and have tried to challenge the "natural laboratory" discourse, but with little success due to the power of tour operators and their own increasing reliance on tourism $[115,116]$.

\section{Discussion}

Based on the results, we first discuss the identification of barriers for equitable PA governance. We then analyze resistance actions, their scope and their outcomes, and we then discuss the notion of overcoming distance to enable more equitable PA governance.

\subsection{Barriers to Equitable PA Governance}

A first observation is that in the four cases, telecoupling processes related or competing with PAs led to rather inequitable outcomes. We can identify barriers to equitable PA governance by grouping the found power-laden links between telecoupling processes and EJ outcomes (Table 4). These barriers are present in action situations (AS) located at different scales of analysis, not only through transnational ties, but also in national and local arenas. Some identified barriers are also tied to different dimensions of EJ, either to a specific dimension or to a combination of two or three dimensions.

Table 4. Main barriers to equitable governance found in the four studied cases.

\begin{tabular}{|c|c|c|c|c|}
\hline Barrier & Link & Scale & Tied Systems & EJ Dimensions ${ }^{1}$ \\
\hline Wilderness framings & M2, N1, G1 & $\begin{array}{l}\text { Transnational, } \\
\text { National, Local }\end{array}$ & $\begin{array}{l}\text { Europe, USA, } \\
\text { International }\end{array}$ & $\mathrm{R},(\mathrm{P})$ \\
\hline $\begin{array}{l}\text { Negative narratives about } \\
\text { local uses }\end{array}$ & M1, N1, T1 & $\begin{array}{l}\text { Transnational, } \\
\text { National, Local }\end{array}$ & $\begin{array}{c}\text { Central States; } \\
\text { Int + local experts }\end{array}$ & $\mathrm{R},(\mathrm{P})$ \\
\hline Malthusian framings & T7, G5 & National & $\begin{array}{l}\text { Central States, } \\
\text { urban areas }\end{array}$ & $\mathrm{R},(\mathrm{P})$ \\
\hline Rhetoric participation & T4, G3 & $\begin{array}{l}\text { Transnational, } \\
\text { National }\end{array}$ & $\begin{array}{l}\text { Europe, USA, } \\
\text { International }\end{array}$ & $\mathrm{P},(\mathrm{R})$ \\
\hline Authoritarian rule & $\mathrm{M} 4, \mathrm{~N} 2$ & National & Central States & $\mathrm{P},(\mathrm{R})$ \\
\hline $\begin{array}{c}\text { Socio-cultural } \\
\text { discriminations + conflicts }\end{array}$ & N4,T5 & National, Local & $\begin{array}{l}\text { Regional and ethnic } \\
\text { identities }\end{array}$ & $\mathrm{R}, \mathrm{P}, \mathrm{D}$ \\
\hline Financial dependence & $\mathrm{M} 3, \mathrm{~T} 2, \mathrm{~N} 3, \mathrm{G} 2$ & Transnational & $\begin{array}{c}\text { Europe }+ \\
\text { USA-country relation }\end{array}$ & $\mathrm{D},(\mathrm{P})$ \\
\hline $\begin{array}{l}\text { Extractive demand } \\
\text { pressure }\end{array}$ & M6, N5, G7, T6 & $\begin{array}{l}\text { Transnational, } \\
\text { National, Local }\end{array}$ & $\begin{array}{l}\text { Asia, Europe, USA, } \\
\text { Urban areas }\end{array}$ & $\mathrm{D}$ \\
\hline $\begin{array}{l}\text { Narrow development } \\
\text { options }\end{array}$ & N6, G6 & $\begin{array}{l}\text { Transnational, } \\
\text { National }\end{array}$ & Urban areas & $\mathrm{D}$ \\
\hline Tourism demand pressure & $\mathrm{T} 3, \mathrm{~N} 3, \mathrm{G} 2, \mathrm{G} 4$ & $\begin{array}{l}\text { Transnational, } \\
\text { National, Local }\end{array}$ & $\begin{array}{l}\text { USA, Europe, } \\
\text { Urban areas }\end{array}$ & $\mathrm{R},(\mathrm{D})$ \\
\hline
\end{tabular}

${ }^{1} \mathrm{R}=$ Recognition; $\mathrm{P}=$ Procedure; $\mathrm{D}=$ Distribution. 
Dominant discourses and narratives have a predominant influence on recognition but also affect procedures. Wilderness framings and negative narratives on local uses and practices often come together and were found in AS at all scales including transnational conceptualization of PAs, support to national policies and local management. Malthusian framings were more frequently found at national scale. These narratives make co-existence of people and nature difficult, hampering recognition in the first place, but also hampering procedures, leaving very little negotiation space for local populations and the acceptance of their practices and knowledge.

Socio-political power configurations are mainly found at national and local scale, but can have a strong influence on how the international discourse on participation is implemented in practice. Our observations showed that participation either did not give local communities true decision-making power (Tunari), or was captured by specific interest groups, such as fishermen (Galapagos) [120]. Authoritarian rule acts on procedures but also on recognition. In the two African cases, it made participation very difficult and also hampered the establishment and respect of local rights. These observations show the importance of national and local AS in shaping power relationships. Socio-cultural discrimination was mainly expressed at local scale, involving overlapping ethnic and regional divisions (Nech Sar) or ethnic and urban-rural divisions (Tunari). Discrimination has often strong historical backgrounds, and acts on the three dimensions of EJ by reinforcing misrecognition, hindering the participation of some groups in decision-making, restricting their access to benefits and increasing their risk of assuming burdens.

In the four observed cases, the dependence of PAs on international funding was prevalent, confirming a general trend in the Global South [78]. This situation clearly builds on the broader international distribution of economic power. From a world-system perspective [124], it makes conservation areas an expression of the asymmetric power relations between core and periphery. On the one hand, dependence represents a barrier for more equitable procedures by making downward accountability more difficult. On the other hand, dependence also makes PAs unsecure: in the four cases, we observed discontinuities in international support. These led to a shift from participatory back to authoritarian governance (Masoala, Nech Sar) while simultaneously opening up opportunities for illegal extraction of resources or park invasion, with strong negative effects in terms of EJ (all cases). We observed strong extractive pressures stemming from transnational, national and local networks. These pressures act mainly on distribution, giving economic power to specific groups that can capture the benefits of these pressures, and use this power to further weaken procedures, feeding back into other aspects of EJ and reinforcing other barriers. Narrow development options such as the lack of energy alternatives for the city of Arba Minch or the economic crisis in mainland Ecuador act rather indirectly on EJ outcomes through immigration and extraction. While tourism demand can be an opportunity to support PAs, it can also be represent a limitation for equitable governance in terms of recognition when it is tied to wilderness narratives.

Our observations show that barriers to equitable governance often do not act in isolation, but reinforce each other, especially when they are rooted in AS found at different scales, such as for example, the combination of transnational wilderness framing and national authoritarian rule, or the combination of dependence on international funding and transnational extractive pressures. Actors who are subjected to unfavorable power relationships generated along multiple telecoupling processes face particularly challenges to be treated equitably. Even if processes do not occur simultaneously and provide short-term and temporary benefits, competing conservation and extraction telecouplings can have cumulative long-term impacts that multiply burdens to local populations, as was observed in Masoala. In such cases, competing telecouplings create situations of multiple impact exposures that are tied to multiple sources of exclusion. Instead of representing ungoverned processes [22], illegal extraction processes that are tied to distant systems frequently give rise to de facto enclosures driven by actors from diverse areas and backgrounds. Besides negative social impacts, these situations have also strongly negative ecological impacts when these powerful actors rush into the resource and quickly deplete it [125]. 
Another observation driven from the assessment of barriers to equity through the telecoupling lens is the ubiquity of supply chains found in conservation, extraction and other telecouplings. This stresses the need to bring closer existing research on equity in supply chains, to PA governance. Considering justice along supply chains confronts different concepts of fairness: while "neoclassic economics rules out the very notion of a market transaction being unjust" [16] (p. 83), integrating the ecological and social-ecological costs of these transactions clearly identifies a concentration of burdens at production and extraction sites [16], and a concentration of power for those who are able to control bottlenecks in the chain. Thus, telecoupled supply chains of extraction represent a burden shifting from consumer sites to producer sites, making these chains likely unjust in social-ecological terms, especially if they operate under declining terms of trade. While aspects of procedural and distributive justice have been explored in supply chain relationships [126], the recognition dimension needs more investigations.

\subsection{Resistance Actions}

Understanding multiple telecouplings as multiple sources of exclusion also enables the understanding of resistance actions as "multiple options for emancipation". Table 5 summarizes the resistance actions reported for the four cases. We labelled actions that improved EJ outcomes according to the involved actor's claims in the revised literature as successful. Partial success includes actions that have advanced the actors' agenda, but without yet securing equity.

Table 5. Main resistance actions reported in the four studied cases.

\begin{tabular}{|c|c|c|c|c|}
\hline Action & Type & Actors & Target (Scale) & Success \\
\hline \multicolumn{5}{|c|}{ Masoala National Park } \\
\hline Avoid park projects & Passive resistance & Small farmers & Local & Partial \\
\hline Block loggers & Active resistance & Small farmers & Local & No \\
\hline CITES lobbying & International advocacy & International NGOs & Global & Yes \\
\hline Track shipping companies & International advocacy & International NGOs & Transnational & Partial \\
\hline Advocacy in China & Transnational advocacy & International NGOs & Transnational & Partial \\
\hline Pressure government & Transnational advocacy & International NGOs & Transnational & Partial \\
\hline Human rights advocacy & Transnational advocacy & Swiss and national NGO & Transnational & Partial \\
\hline \multicolumn{5}{|c|}{ Tunari National Park } \\
\hline Work conditions claims & Active resistance & Small farmers & Local & Yes \\
\hline Board withdrawal & Passive resistance & Farmers association & Local & No \\
\hline Forestry project withdrawal & Passive resistance & Small farmers & Local & No \\
\hline National movement support & National politics & Farmers association & National & Partial \\
\hline Land occupation & Active resistance & Small farmers & Local & Unknown \\
\hline Place care narrative & Counter-narrative & Small farmers & Multiple & Partial \\
\hline \multicolumn{5}{|c|}{ Nech Sar National Park } \\
\hline Looting + wildlife killings & Violent actions & Pastoralists + Farmers & Local & No \\
\hline Land occupation & Active resistance & Pastoralists + Farmers & Local & No \\
\hline Fire suppression blame & Counter-narrative & Pastoralists & Multiple & Partial \\
\hline Alliance with regions++ & National politics & Pastoralists & National & Partial \\
\hline \multicolumn{5}{|c|}{ Galapagos National Park and Marine Reserve } \\
\hline Looting + wildlife killings & Violent actions & Fishermen & Local & Yes \\
\hline Alliances with national parties & National politics & Fishermen & National & Yes \\
\hline Strikes, demonstrations & Active resistance & Fishermen & Local & Partial \\
\hline Challenging "natural laboratory" & Counter-narrative & Fishermen & Multiple & No \\
\hline
\end{tabular}

One can first observe that most actions targeted local AS such as park management and structures. Reaching distant AS was rarely directly possible for people affected by the examined processes. However, they were partly able to reach them through alliances with NGOs, with national political parties, with social movements and with regional governments. True transnational action was only reported for Masoala, with international NGOs acting on flows and performing advocacy at multiple scales of action. In this case, it makes sense to make a difference between global actions, which aim at influencing global regulations, and transnational actions, which aim at addressing ties linking distant nations. 
Chances of success for actions appear not to be dependent on the scale of action, since successful actions were observed at all scales. However, when local actions were not successful, up-scaling them seemed to increase their chances of success, as observed in the Tunari case and partly in the Nech Sar case. Local violent actions had little success, except in the Galapagos where it forced park and government authorities to negotiate. In general, we observe that actions that fit with the scale of the telecoupling process involved are more likely to succeed.

In three cases, the diffusion of counter-narratives as a form of resistance was observed. Through flows of information, counter-narratives can potentially reach multiple scales of AS and increase their chances of success. They, however, depend on the strength of the narrative they aim at questioning. For example, in the Galapagos, fishermen were not able to challenge the idea of "natural laboratory", though in Tunari and Nech Sar they partly challenged wilderness approaches.

\subsection{Telecouplings and Environmental Justice: A Question of Distance?}

Assuming that the chances of success of actions are likely to be higher if actors are able to cross, link and control distant AS makes the notion of distance crucial to understand power relations. Eakin et al. (2017) [66] argue that bridging physical, institutional or social distance entails transaction costs that make distant systems more challenging to govern. This means that the actors who can overcome these transaction costs gain prevalent influence and power by "mobiliz[ing] constituents in multiple geographies" [66] (p. 32). Who do then these different types of distance shape transformation options?

Physical distance seems to be particularly relevant for procedural justice, since excluded actors cannot physically reach the decision-making arena to which they are subjected. Local people and civil society groups in the Global South are less likely to be able to claim participation in decision-making than conservation NGOs, national governments or big business actors. This can be interpreted as a mismatch between actors benefiting from governance processes and those subjected to them, with powerful actors able to create and enforce rules that are valid for others, but to which they are not subjected. Those in disadvantage are likely to perceive such mismatch as a strong injustice and actively fight it. To overcome physical distance, local actors necessarily need to build alliances with actors who are able to cover the involved transaction costs, such as political parties, regional governments or NGOs.

Physical distance does not, however, completely explain barriers to procedural justice. PA governance by regional or national government with little external support also led to equity issues. In these cases, major barriers to procedural justice were authoritarian rule, which can be related to institutional distance, and the social discrimination of specific groups, which can be related to social distance. Social distance emerges when social groups have few relations and mutual understanding, and is therefore also relevant to recognition. Wilderness framings and negative narratives on local uses and practices can also be understood as consequences of social distance, for example between tourists and local people. Social distance enhances misrecognition by hampering mutual understanding and the emergence of social learning and communicative action. Inversely, negative narratives about local uses can widen social distance even if telecoupled systems bring them closer through flows of information and people [96]. These narratives are reinforced if they build on already existing social distance between groups at national or local scale.

Physical and social distance can reinforce each other through psychological distance, which captures aspects of meaning common to all distances, since people often tend to think about events that are distant in one dimension as also being distant in other dimensions [127]. Nevertheless, increased mobility of people and information can also bring people socially closer despite physical distance through shared place attachment, opening up new potentials for cross-scale alliances in governing and managing PAs [128].

To sum up, actors need to overcome transaction costs to overcome physical, institutional and social distance to enable their access to the AS to which they are subjected. Building alliances across scales 
can be interpreted as a reduction of social distance and the buildup of place attachment communities. Nevertheless, it can also confer substantial power to those actors able to bridge distance, raising equity issues for those not able to. In the introduction, we assumed that more equitable governance of PA is likely to lead to more effective conservation. The case of the Galapagos, which is the one where local actors have gained more bargaining power, seems rather to infer this view, since more equity was not able to curb threats to biodiversity. Nevertheless, in this case, a specific group captured bargaining power; they framed equity aspects mainly in distributive terms and they did not question the model of tourism development, which is the main attractor of migration.

Alliances that build across physical and social distance to transform EJ outcomes raise further questions on the suitability of a networked approach to capture them. McFarlane [129] argues that the notion of translocal assemblages, which also captures the temporality, the labor and materiality invested and the performance of social connections, might be better suited to understand these alliances. For example, the elaboration of shared counter-narratives to overcome distance and mobilize multiple options for emancipation appears crucial. Such counter-narratives might involve making visible the telecoupling processes that compete with conservation, and challenging discourses that focus on proximate rather than on underlying causes of biodiversity decline. Yet producing and diffusing these counter-narratives involve substantial resources and capabilities, which might be beyond the reach of many local actors affected by these discourses.

\section{Conclusions}

Our study, based on four cases of PAs in the Global South, made it possible to establish conceptual bridges between the telecoupling framework and a tri-dimensional understanding of EJ. Considering them as complementary approaches has a high potential to understand conservation contexts better and explore transformation options to make biodiversity conservation more just and effective.

Incorporating an EJ perspective into telecoupling is particularly useful to understand the relationships between actors and existing asymmetric power relationships from both a normative and empirical perspective. Such incorporation can make a substantial contribution to account for power asymmetries in polycentric governance research. The telecoupling approach can incorporate dynamic governance elements, such as the notion of action situations, but must be developed further to connect with normative frameworks such as EJ to make power asymmetries visible.

Based on our findings, we argue that to do this, institutional analysis in telecoupled systems first requires a more thorough analysis of the discourses and narratives deployed by the actors [70], as well as the resonance of these discourses. Second, the relationships between the actors need to be understood in terms of physical, social and institutional distance [66]. For example, how social groups see each other could can reveal key aspects of social distance that represent barriers to participation, recognition and more just and sustainable governance. Third, one needs to consider the resources, in terms of labor, capabilities and capital that actors can mobilize to bridge different types of distance and increase their chances of advancing their agenda in action situations. Multiple sources of exclusion tied with multiple telecoupling contexts add up distances to overcome and are particularly challenging.

We also suggest that one should open up the analysis of the different spatial imaginaries that the actors develop in their claims. While the identification of telecoupling processes through flows is useful, we observe that territorial governance still plays an important role in shaping decision-making and EJ outcomes, especially when administrative national and sub-national jurisdictions are involved, and that territories are actively mobilized as spatial imaginaries. In this sense, shifting from territorial to networked approaches and vice versa can be interpreted as strategies to build narratives and counter-narratives in biodiversity conservation.

In this study, we could only capture some clues on how actors perceive each other and what their spatial imaginaries were. We suggest that future empirical research on telecouplings include more systematically these dimensions and deepen these aspects. 
Author Contributions: Conceptualization: S.B., J.-D.G., C.O., J.G.Z., C.I.S., and S.R.; data curation: S.B. and J.G.Z.; formal analysis: S.B. and J.G.Z.; funding acquisition: J.-D.G., C.O., J.G.Z., and S.R.; investigation: S.B. and J.G.Z.; methodology, S.B., J.-D.G., C.O., C.I.S., and S.R.; project administration: J.-D.G. and C.I.S.; supervision: J.-D.G., C.I.S., and S.R.; visualization: S.B.; writing—original draft: S.B.; writing—review and editing: S.B., J.-D.G., C.O., J.G.Z., C.I.S., and S.R.

Funding: This research was funded and performed by the research cluster group on "Governing telecoupled natural resource systems for environmental justice", a joint initiative of the Institute of Geography and the Centre for Development and Environment at the University of Bern, Switzerland. Julie Zaehringer's work was also supported by the Swiss Programme for Research on Global Issues for Development (grant number 400440152167 ).

Acknowledgments: This work was performed by The authors would like to thank Asebe Regassa Debelo, Christophe Grenier, René Herbas, Eva Keller, Girma Kelboro and Philippe Vaneberg for their valuable information and reviews on the specific PA cases. We also thank Andrea Weber for her help on the figures.

Conflicts of Interest: The authors declare no conflict of interest.

\section{References}

1. Thomas, C.D.; Gillingham, P.K.; Bradbury, R.B.; Roy, D.B.; Anderson, B.J.; Baxter, J.M.; Bourn, N.A.D.; Crick, H.Q.P.; Findon, R.A.; Fox, R.; et al. Protected areas facilitate species' range expansions. Proc. Natl. Acad. Sci. USA 2012, 109, 14063-14068. [CrossRef] [PubMed]

2. UNEP-WCMC; IUCN. Protected Planet Report 2016; UNEP-WCMC: Gland, Switzerland; IUCN: Cambridge, UK, 2016.

3. Mace, G.M.; Cramer, W.; Díaz, S.; Faith, D.P.; Larigauderie, A.; Le Prestre, P.; Palmer, M.; Perrings, C.; Scholes, R.J.; Walpole, M.; et al. Biodiversity targets after 2010. Curr. Opin. Environ. Sustain. 2010, 2, 3-8. [CrossRef]

4. Butchart, S.H.M.; Walpole, M.; Collen, B.; van Strien, A.; Scharlemann, J.P.W.; Almond, R.E.A.; Baillie, J.E.M.; Bomhard, B.; Brown, C.; Bruno, J.; et al. Global Biodiversity: Indicators of Recent Declines. Science 2010, 328, 1164-1168. [CrossRef] [PubMed]

5. Rockstrom, J.; Steffen, W.; Noone, K.; Persson, A.; Chapin, F.S.; Lambin, E.F.; Lenton, T.M.; Scheffer, M.; Folke, C.; Schellnhuber, H.J.; et al. A safe operating space for humanity. Nature 2009, 461, 472-475. [CrossRef] [PubMed]

6. Wilson, E.O. Half-Earth: Our Planet's Fight for Life; Liveright Publishing Corporation: New York, NY, USA; London, UK, 2016.

7. Mascia, M.B.; Pailler, S. Protected area downgrading, downsizing, and degazettement (PADDD) and its conservation implications. Conserv. Lett. 2011, 4, 9-20. [CrossRef]

8. Laurance, W.F.; Carolina Useche, D.; Rendeiro, J.; Kalka, M.; Bradshaw, C.J.A.; Sloan, S.P.; Laurance, S.G.; Campbell, M.; Abernethy, K.; Alvarez, P.; et al. Averting biodiversity collapse in tropical forest protected areas. Nature 2012, 489, 290-294. [CrossRef] [PubMed]

9. Brockington, D.; Igoe, J. Eviction for Conservation: A Global Overview. Conserv. Soc. 2006, 4, 424-470.

10. West, P.; Igoe, J.; Brockington, D. Parks and Peoples: The Social Impact of Protected Areas. Annu. Rev. Anthropol. 2006, 35, 251-277. [CrossRef]

11. Almudi, T.; Berkes, F. Barriers to empowerment: Fighting eviction for conservation in a southern Brazilian protected area. Local Environ. 2010, 15, 217-232. [CrossRef]

12. Duffy, R. Waging a war to save biodiversity: The rise of militarized conservation. Int. Aff. 2014, 90, 819-834. [CrossRef]

13. Ramutsindela, M. The Contours of Political Transformation and Conservation Areas in Southern Africa. Geogr. Compass 2008, 2, 359-374. [CrossRef]

14. Bennett, N.J.; Roth, R.; Klain, S.C.; Chan, K.M.A.; Clark, D.A.; Cullman, G.; Epstein, G.; Nelson, M.P.; Stedman, R.; Teel, T.L.; et al. Mainstreaming the social sciences in conservation. Conserv. Biol. 2017, 31, 56-66. [CrossRef] [PubMed]

15. Reed, M.S. Stakeholder participation for environmental management: A literature review. Biol. Conserv. 2008, 141, 2417-2431. [CrossRef]

16. Martin, A. Just Conservation. Biodiversity, Well-Being and Sustainability; Earthscan, Routledge: Oxford, UK, 2017. 
17. Oberlack, C.; LaHaela Walter, P.; Schmerbeck, J.; Tiwari, B. Institutions for sustainable forest governance: Robustness, equity, and cross-level interactions in Mawlyngbna, Meghalaya, India. Int. J. Commons 2015, 9, 670-697. [CrossRef]

18. Andrade, G.S.M.; Rhodes, J.R. Protected Areas and Local Communities: An Inevitable Partnership toward Successful Conservation Strategies? Ecol. Soc. 2012, 17. [CrossRef]

19. Oldekop, J.A.; Holmes, G.; Harris, W.E.; Evans, K.L. A global assessment of the social and conservation outcomes of protected areas. Conserv. Biol. 2016, 30, 133-141. [CrossRef] [PubMed]

20. Schlosberg, D. Theorising environmental justice: The expanding sphere of a discourse. Environ. Politics 2013, 22, 37-55. [CrossRef]

21. Liu, J.; Hull, V.; Batistella, M.; DeFries, R.; Dietz, T.; Fu, F.; Hertel, T.W.; Izaurralde, R.C.; Lambin, E.F.; Li, S.; et al. Framing Sustainability in a Telecoupled World. Ecol. Soc. 2013, 18. [CrossRef]

22. Eakin, H.; DeFries, R.; Kerr, S.; Lambin, E.F.; Liu, J.; Marcotullio, P.J.; Messerli, P.; Rueda, X.; Swaffield, S.R.; Wicke, B.; et al. Significance of Telecoupling for Exploration of Land-Use Change. In Rethinking Global Land Use in an Urban Era; Seto, K., Reenberg, A., Eds.; MIT Press: Cambridge, MA, USA, 2014; pp. 141-162. ISBN 978-0-262-02690-1.

23. Oberlack, C.; Boillat, S.; Brönnimann, S.; Gerber, J.-D.; Heinimann, A.; Ifejika Speranza, C.; Messerli, P.; Rist, S.; Wiesmann, U. Polycentric governance in telecoupled resource systems. Ecol. Soc. 2018, 23. [CrossRef]

24. Kimmich, C. Linking action situations: Coordination, conflicts, and evolution in electricity provision for irrigation in Andhra Pradesh, India. Ecol. Econ. 2013, 90, 150-158. [CrossRef]

25. Walker, G. Beyond Distribution and Proximity: Exploring the Multiple Spatialities of Environmental Justice. Antipode 2009, 41, 614-636. [CrossRef]

26. Rawls, J. A Theory of Justice; Belknap: Cambridge, MA, USA, 1971.

27. Sen, A. The Idea of Justice; Allen Lane \& Harvard University Press: Cambridge, MA, USA, 2009.

28. Fraser, N. Identity, Exclusion, and Critique: A Response to Four Critics. Eur. J. Political Theory 2007, 6, 305-338. [CrossRef]

29. Fraser, N. Recognition without Ethics? Theory Cult. Soc. 2001, 18, 21-42. [CrossRef]

30. Honneth, A. Recognition or Redistribution? Theory Cult. Soc. 2001, 18, 43-55. [CrossRef]

31. Young, I.M. Justice and the Politics of Difference; Princeton University Press: Princeton, NJ, USA, 1990.

32. Taylor, D.E. The Rise of the Environmental Justice Paradigm: Injustice Framing and the Social Construction of Environmental Discourses. Am. Behav. Sci. 2000, 43, 508-580. [CrossRef]

33. Mohai, P.; Pellow, D.; Roberts, J.T. Environmental Justice. Annu. Rev. Environ. Resour. 2009, 34, 405-430. [CrossRef]

34. Agyeman, J.; Schlosberg, D.; Craven, L.; Matthews, C. Trends and Directions in Environmental Justice: From Inequity to Everyday Life, Community, and Just Sustainabilities. Annu. Rev. Environ. Resour. 2016, 41, 321-340. [CrossRef]

35. Schlosberg, D. Reconceiving Environmental Justice: Global Movements And Political Theories. Environ. Politics 2004, 13, 517-540. [CrossRef]

36. Gottlieb, R. Where We Live, Work, Play and Eat: Expanding the Environmental Justice Agenda. Environ. Justice 2009, 2, 7-8. [CrossRef]

37. Martin, A.; McGuire, S.; Sullivan, S. Global environmental justice and biodiversity conservation. Geogr. J. 2013, 179, 122-131. [CrossRef]

38. Sikor, T. The Justices and Injustices of Ecosystem Services; Routledge: Oxford, UK, 2014.

39. De Jonge, B. What is Fair and Equitable Benefit-sharing? J. Agric. Environ. Ethics 2011, 24, 127-146. [CrossRef]

40. McDermott, M.; Mahanty, S.; Schreckenberg, K. Examining equity: A multidimensional framework for assessing equity in payments for ecosystem services. Environ. Sci. Policy 2013, 33, 416-427. [CrossRef]

41. Berkes, F. Evolution of co-management: Role of knowledge generation, bridging organizations and social learning. J. Environ. Manag. 2009, 90, 1692-1702. [CrossRef] [PubMed]

42. Gorenflo, L.J.; Romaine, S.; Mittermeier, R.A.; Walker-Painemilla, K. Co-occurrence of linguistic and biological diversity in biodiversity hotspots and high biodiversity wilderness areas. Proc. Natl. Acad. Sci. USA 2012, 109, 8032-8037. [CrossRef] [PubMed]

43. Martin, A.; Coolsaet, B.; Corbera, E.; Dawson, N.M.; Fraser, J.A.; Lehmann, I.; Rodriguez, I. Justice and conservation: The need to incorporate recognition. Biol. Conserv. 2016, 197, 254-261. [CrossRef] 
44. Zafra-Calvo, N.; Pascual, U.; Brockington, D.; Coolsaet, B.; Cortes-Vazquez, J.A.; Gross-Camp, N.; Palomo, I.; Burgess, N.D. Towards an indicator system to assess equitable management in protected areas. Biol. Conserv. 2017, 211, 134-141. [CrossRef]

45. Schreckenberg, K.; Franks, P.; Martin, A.; Lang, B. Unpacking equity for protected area conservation. Parks 2016, 22, 11-26. [CrossRef]

46. Dawson, N.; Martin, A.; Danielsen, F. Assessing Equity in Protected Area Governance: Approaches to Promote Just and Effective Conservation. Conserv. Lett. 2017, 11, 1-8. [CrossRef]

47. Franks, P.; Martin, A.; Schreckenberg, K. From Livelihoods to Equity for Better Protected Area Conservation; International Institute for Environment and Development Briefing: London, UK, 2016.

48. Agyeman, J.; Carmin, J. Environmental Inequalities Beyond Borders: Local Perspectives on Global Injustices; MIT Press: Cambridge, MA, USA, 2011.

49. Sikor, T.; Newell, P. Globalizing environmental justice? Geoforum 2014, 54, 151-157. [CrossRef]

50. Miranda, M.L.; Hastings, D.A.; Aldy, J.E.; Schlesinger, W.H. The Environmental Justice Dimensions of Climate Change. Environ. Justice 2011, 4, 17-25. [CrossRef]

51. Guha, R. Radical American Environmentalism and Wilderness Preservation: A Third World Critique. Environ. Ethics 1989, 11, 71-83. [CrossRef]

52. Martinez-Alier, J. The environmentalism of the poor. Geoforum 2014, 54, 239-241. [CrossRef]

53. Holifield, R. Environmental Justice and Political Ecology. In The Routledge Handbook of Political Ecology; Perreault, T., Bridge, G., McCarthy, J., Eds.; Routledge: Oxford, UK; New York, NJ, USA, 2015; pp. 585-597.

54. Nancy, F. Who Counts? Dilemmas of Justice in a Postwestphalian World. Antipode 2010, 41, $281-297$. [CrossRef]

55. Buller, J. State spatiality in an era of global and regional interdependence: The linkage governance approach. Comp. Eur. Politics 2018, 16, 224-248. [CrossRef]

56. Painter, J. Territoire et réseau: Une fausse dichotomie? [Territory and network: A false dichotomy?]. In Territoires, Territorialité, Territorialisation: Controverses et Perspectives; Vanier, M., Ed.; Presses Universitaires de Rennes: Rennes, France, 2009; pp. 57-66.

57. Gibson-Graham, J.K. Beyond Global vs. Local: Economic Politics Outside the Binary Frame. In Geographies of Power: Placing Scale; Herod, A., Wright, M.W., Eds.; Blackwell Publishers Ltd: Oxford, UK, 2002; pp. 25-60. ISBN 9780470773406.

58. Herod, A. Scale: The local and the global. In Key Concepts in Geography; Clifford, N.J., Holloway, S.L., Rice, S.P., Gill, V., Eds.; Sage Publishers: Los Angeles, CA, USA; London, UK; New Delhi, India; Singapore; Washington, DC, USA, 2009; pp. 217-235.

59. Latour, B. Nous N'avons Jamais été Modernes. Essai D'anthropologie Symétrique; La découverte: Paris, France, 1997.

60. Sikor, T.; Auld, G.; Bebbington, A.J.; Benjaminsen, T.A.; Gentry, B.S.; Hunsberger, C.; Izac, A.M.; Margulis, M.E.; Plieninger, T.; Schroeder, H.; et al. Global land governance: From territory to flow? Curr. Opin. Environ. Sustain. 2013, 5, 522-527. [CrossRef]

61. Beck, U. Risk Society: Towards a New Modernity; SAGE Publications Ltd.: Los Angeles, CA, USA; London, UK; New Delhi, India; Singapore; Washington, DC, USA, 1992.

62. Young, I.M. Responsibility and global justice: A social connection model. Soc. Philos. Policy 2006, 23, 102-130. [CrossRef]

63. Lenschow, A.; Newig, J.; Challies, E. Globalization's limits to the environmental state? Integrating telecoupling into global environmental governance. Environ. Politics 2016, 25, 136-159. [CrossRef]

64. Liu, J.; Dietz, T.; Carpenter, S.R.; Alberti, M.; Folke, C.; Moran, E.; Pell, A.N.; Deadman, P.; Kratz, T.; Lubchenco, J.; et al. Complexity of Coupled Human and Natural Systems. Science 2007, 317, 1513-1516. [CrossRef] [PubMed]

65. Meyfroidt, P.; Rudel, T.K.; Lambin, E.F. Forest transitions, trade, and the global displacement of land use. Proc. Natl. Acad. Sci. USA 2010, 107, 20917-20922. [CrossRef] [PubMed]

66. Eakin, H.; Rueda, X.; Mahanti, A. Transforming governance in telecoupled food systems. Ecol. Soc. 2017, 22. [CrossRef]

67. Ostrom, E. Polycentric systems for coping with collective action and global environmental change. Glob. Environ. Chang. 2010, 20, 550-557. [CrossRef] 
68. Ostrom, E. A General Framework for Analyzing Sustainability of Social-Ecological Systems. Science 2009, 325, 419-422. [CrossRef] [PubMed]

69. Ostrom, E. Background on the Institutional Analysis and Development Framework. Policy Stud. J. 2011, 39, 7-27. [CrossRef]

70. Clément, F. For critical social-ecological system studies: Integrating power and discourses to move beyond the right institutional fit. Environ. Conserv. 2013, 40, 1-4. [CrossRef]

71. Isaac, J.C.; Bermeo, N.; Levi, M.; Baumgartner, F.R.; Keohane, R.O.; Axelrod, R.; Fine, B.; Schwartz-Shea, P.; Mansbridge, J. Beyond the Tragedy of the Commons A Discussion of "Governing the Commons: The Evolution of Institutions for Collective Action". Perspect. Politics 2010, 8, 569-593. [CrossRef]

72. Friis, C.; Nielsen, J.Ø.; Otero, I.; Haberl, H.; Hostert, P. From teleconnection to telecoupling: Taking stock of an emerging framework in land system science. J. Land Use Sci. 2015, 4248, 1-23. [CrossRef]

73. Maxwell, S.L.; Fuller, R.A.; Brooks, T.M.; Watson, J.E.M. Biodiversity: The ravages of guns, nets and bulldozers. Nature 2016, 536, 143-145. [CrossRef] [PubMed]

74. Weinzettel, J.; Hertwich, E.G.; Peters, G.P.; Steen-Olsen, K.; Galli, A. Affluence drives the global displacement of land use. Glob. Environ. Chang. 2013, 23, 433-438. [CrossRef]

75. Lenzen, M.; Moran, D.; Kanemoto, K.; Foran, B.; Lobefaro, L.; Geschke, A. International trade drives biodiversity threats in developing nations. Nature 2012, 486, 109-112. [CrossRef] [PubMed]

76. Liu, J.; Dou, Y.; Batistella, M.; Challies, E.; Connor, T.; Friis, C.; Millington, J.D.A.; Parish, E.; Romulo, C.L.; Silva, R.F.B.; et al. Spillover systems in a telecoupled Anthropocene: Typology, methods, and governance for global sustainability. Curr. Opin. Environ. Sustain. 2018, 33, 58-69. [CrossRef]

77. Carrasco, L.R.; Chan, J.; McGrath, F.L.; Nghiem, L.T.P. Biodiversity conservation in a telecoupled world. Ecol. Soc. 2017, 22. [CrossRef]

78. Miller, D.C.; Agrawal, A.; Roberts, J.T. Biodiversity, Governance, and the Allocation of International Aid for Conservation. Conserv. Lett. 2013, 6, 12-20. [CrossRef]

79. Balmford, A.; Green, J.M.H.; Anderson, M.; Beresford, J.; Huang, C.; Naidoo, R.; Walpole, M.; Manica, A. Walk on the Wild Side: Estimating the Global Magnitude of Visits to Protected Areas. PLoS Biol. 2015, 13, 1-6. [CrossRef] [PubMed]

80. Myers, N.; Mittermeier, R.A.; Mittermeier, C.G.; da Fonseca, G.A.B.; Kent, J. Biodiversity hotspots for conservation priorities. Nature 2000, 403, 853-858. [CrossRef] [PubMed]

81. Gissibl, B.; Höhler, S.; Kupper, P. Civilizing Nature: National Parks in Global Historical Perspective; Berghahn Books: New York, NY, USA; Oxford, UK, 2012; ISBN 978-1-78238-908-8.

82. Roberts, S.M.; Jones III, J.P.; Fröhling, O. NGOs and the globalization of managerialism: A research framework. World Dev. 2005, 33, 1845-1864. [CrossRef]

83. Sodikoff, G. The Low-Wage Conservationist: Biodiversity and Perversities of Value in Madagascar. Am. Anthropol. 2009, 111, 443-455. [CrossRef]

84. Fairhead, J.; Leach, M.; Scoones, I. Green Grabbing: A new appropriation of nature? J. Peasant Stud. 2012, 39, 237-261. [CrossRef]

85. Peluso, N.L.; Lund, C. New frontiers of land control: Introduction. J. Peasant Stud. 2011, 38, 667-681. [CrossRef]

86. Harvey, D. A Brief History of Neoliberalism; Oxford University Press: Oxford, UK, 2005; ISBN 0-19-162294-X.

87. Brockington, D.; Duffy, R.; Igoe, J. Nature Unbound: Conservation, Capitalism and the Future of Protected Areas; Earthscan: London, UK; Sterling, VA, USA, 2008.

88. Fraser, N. Injustice at Intersecting Scales: On "Social Exclusion" and the "Global Poor". Eur. J. Soc. Theory 2010, 13, 363-371. [CrossRef]

89. Fraser, N. A triple movement? Parsing the Politics of Crisis after Polanyi. In Beyond Neoliberalism. Approaches to Social Inequality and Difference; Burchardt, M., Kirn, G., Eds.; Palgrave Macmillan: London, UK, 2017; pp. $29-42$.

90. Liu, J.; Hull, V.; Luo, J.; Yang, W.; Liu, W.; Viña, A.; Vogt, C.; Xu, Z.; Yang, H.; Zhang, J.; et al. Multiple telecouplings and their complex interrelationships. Ecol. Soc. 2015, 20, 44. [CrossRef]

91. Mace, G.M. Whose conservation? Science 2014, 345, 1558-1560. [CrossRef] [PubMed]

92. Dudley, N. Guidelines for Applying Protected Area Management Categories; IUCN: Gland, Switzerland, 2008.

93. Galvin, M.; Haller, T. People, Protected Areas and Global Change: Participatory Conservation in Latin America, Africa, Asia and Europe; Geographica Bernensia: Bern, Switzerland, 2008. 
94. Sikor, T.; Martin, A.; Fisher, J.; He, J. Toward an Empirical Analysis of Justice in Ecosystem Governance. Conserv. Lett. 2014, 7, 524-532. [CrossRef]

95. Kremen, C.; Razafimahatratra, V.; Guillery, R.P.; Rakotomalala, J.; Weiss, A.; Ratsisompatrarivo, J.-S. Designing the Masoala National Park in Madagascar Based on Biological and Socioeconomic Data. Conserv. Biol. 1999, 13, 1055-1068. [CrossRef]

96. Keller, E. Beyond the Lens of Conservation. Malagasy and Swiss Imaginations of One Another; Berghahn Books: New York, NY, USA; Oxford, UK, 2015.

97. Ormsby, A.; Kaplin, B.A. A framework for understanding community resident perceptions of Masoala National Park, Madagascar. Environ. Conserv. 2005, 32, 156-164. [CrossRef]

98. Kull, C.A. Isle of Fire. The Political Ecology of Landscape Burning in Madagascar; The University of Chicago Press: Chicago, IL, USA, 2004.

99. Randriamalala, H.; Liu, Z. Rosewood of Madagascar: Between democracy and conservation. Madag. Conserv. Dev. 2010, 5, 11-22. [CrossRef]

100. Ratsimbazafy, C.; Netwon, D.J.; Ringuet, S. Timber Island. The Rosewood and Ebony Trade of Madagascar; TRAFFIC: Pretoria, South Africa, 2016; ISBN 978-1-85850-412-4.

101. Danthu, P.; Penot, E.; Ranoarisoa, K.M.; Rakotondravelo, J.C.; Michel, I.; Tiollier, M.; Michels, T.; Normand, F.; Razafimamonjison, G.; Fawbush, F.; et al. The clove tree of Madagascar: A success story with an unpredictable future. Bois For. Trop. 2014, 320, 83-96. [CrossRef]

102. Zaehringer, J.G.; Schwilch, G.; Andriamihaja, O.R.; Ramamonjisoa, B.; Messerli, P. Remote sensing combined with social-ecological data: The importance of diverse land uses for ecosystem service provision in north-eastern Madagascar. Ecosyst. Serv. 2017, 25, 140-152. [CrossRef]

103. Global Witness and Environmental Investigation Agency. Investigation into the Illegal Felling, Transport and Export of Precious Wood in SAVA Region Madagascar. 2009. Available online: https:/ content.eia-global. org/assets/2009/08/Investigation_Into_the_Illegal_Felling_of_Wood_in_Madagascar.pdf (accessed on 26 July 2016).

104. Ovando Sanz, J.A. La Media Luna Cochabambina y Otros Parques Nacionales; Editora "Siglo": La Paz, Bolivia, 1988.

105. Zimmerer, K.S. Soil Erosion and Social (Dis)courses in Cochabamba, Bolivia: Perceiving the Nature of Environmental Degradation. Econ. Geogr. 1993, 69, 312-327. [CrossRef]

106. Boillat, S.; Rist, S.; Serrano, E.; Ponce, D.; Delgadillo, J. Struggling "ontological communities": Transformations of conservationists' and peasants' discourses in the Tunari National Park in Bolivia. In People, Protected Areas and Global Change: Participatory Conservation in Latin America, Africa, Asia and Europe; Galvin, M., Haller, T., Eds.; Geographica Bernensia: Bern, Switzerland, 2008; pp. 37-80.

107. Espinosa, C.; Van Damme, P.; Herbas, R. Plan de Manejo Parque Nacional Tunari 2017-2026; Unpublished Report; FAUNAGUA: Cochabamba, Bolivia, 2016.

108. Lerch, L. The Geopolitics of Land: Population, Security and Territory Viewed from the International Financing of the Land Survey in Bolivia (1996-2013). J. Lat. Am. Geogr. 2014, 13, 137-168. [CrossRef]

109. Biressu, A.N. Resettlement and Local Livelihoods in Nechsar National Park, Southern Ethiopia. Master's Thesis, University of Tromsø, Tromso, Norway, 2009.

110. Debelo, R.A. Contesting Views on a Protected Area Conservation and Development in Ethiopia. Soc. Sci. 2012, 1. [CrossRef]

111. Kelboro, G.; Stellmacher, T. Protected areas as contested spaces: Nech Sar National Park, Ethiopia, between "local people", the state, and NGO engagement. Environ. Dev. 2015, 16, 63-75. [CrossRef]

112. Neumann, R.P. Imposing Wilderness: Struggles over Livelihood and Nature Preservation in Africa; University of California Press: Berkeley, CA, USA; Los Angeles, CA, USA, 1998.

113. Alemu, M.M. Household Energy Demand and Its Impact on the Ecological Capital of Nech Sar National Park, Ethiopia. J. Environ. Prot. 2016, 1273-1282. [CrossRef]

114. Fetene, A.; Hilker, T.; Yeshitela, K.; Prasse, R.; Cohen, W.; Yang, Z. Detecting Trends in Landuse and Landcover Change of Nech Sar National Park, Ethiopia. Environ. Manag. 2016, 57, 137-147. [CrossRef] [PubMed]

115. Quiroga, D. Crafting nature: The Galapagos and the making and unmaking of a "natural laboratory". J. Political Ecol. 2009, 16, 123-140. [CrossRef] 
116. Celata, F.; Sanna, V.S. The post-political ecology of protected areas: Nature, social justice and political conflicts in the Galápagos Islands. Local Environ. 2012, 17, 977-990. [CrossRef]

117. Gardener, M.R.; Grenier, C. Linking Livelihoods and Conservation: Challenges Facing the Gal\{á\}pagos Islands. In Island Futures: Conservation and Development across the Asia-Pacific Region; Baldacchino, G., Niles, D., Eds.; Springer: Tokyo, Japan, 2011; pp. 73-85. ISBN 978-4-431-53989-6.

118. Gonzalez, J.A.; Montes, C.; Rodriguez, J.; Tapia, W. Rethinking the Galapagos Islands as a Complex Social-Ecological System: Implications for Conservation and Management. Ecol. Soc. 2008, 13, 13. [CrossRef]

119. Oleas, R. The Galapagos National Park Entrance Fee: A Global Perspective and Options for the Future. Galapafos Report 2007-2008. Available online: https:/ /www.galapagos.org/wp-content/uploads/2012/04/ socio11-entrance-fee.pdf (accessed on 29 November 2017).

120. Jones, P.J.S. A governance analysis of the Galápagos Marine Reserve. Mar. Policy 2013, 41, 65-71. [CrossRef]

121. Epler, B. Tourism, the Economy, Population Growth, and Conservation in Galapagos; Charles Darwin Foundation: Puerto Ayora, Ecuador, 2007; Available online: https:/ /www.galapagos.org/wp-content/uploads/2012/01/ TourismReport1.pdf (accessed on 29 November 2017).

122. Toral-Granda, V. Galapagos Islands: A hotspot of sea cucumber fisheries in Latin America and the Caribbean. FAO Fish. Aquac. Tech. Pap. 2008, 516, 231-253.

123. Palma, J. Galápagos: Prisión y millonaria multa para tripulantes de carguero chino que transportaba tiburones. Mongabay Not. 2017. Available online: https:/ / es.mongabay.com/2017/08/galapagos-prisionmillonaria-multa-tripulantes-carguero-chino-transportaba-tiburones / (accessed on 29 November 2017).

124. Wallerstein, I. The Politics of the World-Economy. The States, the Movements and the Civilizations; Cambridge University Press: Cambridge, UK, 1984.

125. Berkes, F.; Hughes, T.P.; Steneck, R.S.; Wilson, J.A.; Bellwood, D.R.; Crona, B.; Folke, C.; Gunderson, L.H.; Leslie, H.M.; Norberg, J.; et al. Globalization, Roving Bandits, and Marine Resources. Science 2006, 311, 1557-1558. [CrossRef] [PubMed]

126. Griffith, D.A.; Harvey, M.G.; Lusch, R.F. Social exchange in supply chain relationships: The resulting benefits of procedural and distributive justice. J. Oper. Manag. 2006, 24, 85-98. [CrossRef]

127. Trope, Y.; Liberman, N. Construal-level theory of psychological distance. Psychol. Rev. 2010, 117, 440-463. [CrossRef] [PubMed]

128. Gurney, G.G.; Blythe, J.; Adams, H.; Adger, W.N.; Curnock, M.; Faulkner, L.; James, T.; Marshall, N.A. Redefining community based on place attachment in a connected world. Proc. Natl. Acad. Sci. USA 2017, 114, 10077-10082. [CrossRef] [PubMed]

129. McFarlane, C. Translocal assemblages: Space, power and social movements. Geoforum 2009, 40, 561-567. [CrossRef]

(C) 2018 by the authors. Licensee MDPI, Basel, Switzerland. This article is an open access article distributed under the terms and conditions of the Creative Commons Attribution (CC BY) license (http:/ / creativecommons.org/licenses/by/4.0/). 